\title{
18. SILICA DIAGENESIS IN CONTINENTAL RISE AND SLOPE SEDIMENTS OFF EASTERN NORTH AMERICA (SITES 603 AND 605, LEG 93; SITES 612 AND 613, LEG 95) ${ }^{1}$
}

\author{
Jean Thein, Fachrichtung Angewandte Geochemie, Universität des Saarlandes \\ and \\ Ulrich von Rad, Bundesanstalt für Geowissenschaften und Rohstoffe, Hannover ${ }^{2}$
}

\begin{abstract}
Eocene to Cretaceous siliceous sediments of four Deep Sea Drilling Project sites on the continental margin off eastern North America (Sites 603, 605-Leg 93; Sites 612,613-Leg 95) were analyzed for their major geochemical and mineralogical composition. Under different environmental conditions (burial depth, in situ temperature, host-rock facies) of the upper slope to lower rise, conversion of biogenous opal-A to opal-CT took place in biosiliceous chalks and marls older than early middle Eocene. Dense sampling revealed the sharp character of the diagenetic silicification front (seismic reflector $\mathrm{A}^{\mathrm{c}}$ ), which demonstrates a widespread, more or less synchronous (51-53 Ma), rapid change of silicoplankton fertility and preservation, which later led to the marked boundary between an opal-A and an opal-CT diagenetic facies. In clay-rich sediments on the lower rise (Site 603), the opal-A $\rightarrow$ opal-CT transformation is largely retarded, whereas clinoptilolite formation is enhanced. Host-rock composition and the consequent interstitial water chemistry, apparently controlled by palaoclimatology and paleoceanography, appear to be the most important factors influencing the rate and mode of silica diagenesis.

Diagenetic alteration of the primary siliceous oozes to porcellanitic chalks and porcellanites took place only in a narrow equilibrium range of the complex geochemical sediment-pore water system. These ideal conditions were realized in our case and at most sites in the Atlantic Ocean in sediments older that 51 m.y.
\end{abstract}

\section{INTRODUCTION}

Middle to lower Eocene siliceous sediments (Bermuda Rise Formation) were penetrated at four of the DSDP sites of Legs 93 and 95 (603, 605; 612 and 613, respectively) drilled on the New Jersey Transect between the lowermost continental rise and the upper slope (Fig. 1). The diagenetic transition of biogenic opal-A to opal-CT (porcellanite) can be studied at different conditions of burial depth, temperature, and geochemical environment. Parallel analyses of sediment geochemistry and clay mineralogy (Thein and Schäfer, in prep.) and physical rock properties (Wilkens et al., this volume) help to elucidate the conditions under which the formation of porcellanite, chert, and zeolites took place in the Atlantic Ocean in sediments older that $51 \mathrm{Ma}$, and to study the paleoenvironmental framework that influenced this diagenetic path.

Site 603 (Fig. 2) was drilled on the outermost continental rise off Cape Hatteras at a water depth of $4633 \mathrm{~m}$ and shows, below a hiatal boundary covered by mid-Miocene sediments, a lower mid-Eocene to upper Paleocene sequence of porcellanitic radiolarian claystones (Plate 1, Fig. 2) belonging to lithostratigraphic Unit II (van Hinte, Wise, et al., in press). The sediment is quite different from the coeval siliceous nannofossil chalks and limestones at the three other sites, because Site 603 was situated well below the calcite compensation depth (CCD)

\footnotetext{
${ }^{1}$ Poag, C. W., Watts, A. B., et al., Init. Repts, DSDP, 95: Washington (U.S. Govt. Printing Office).

2 Addresses: (Thein): Fachrichtung Angewandte Geochemie, Universităt des Saarlandes. D 6600 Saarbrücken, Federal Republic of Germany; (von Rad) Bundesanstalt für Geowissenschaften und Rohstoffe, Postfach 510153, D 3000 Hannover 51, Federal Republic of Germany.
}

during that time. Sedimentation rate was low $(6 \mathrm{~m} / \mathrm{m}$.y. in Unit II), and it decreased through the variegated claystone sequence of the Upper Cretaceous (Unit III) to $3 \mathrm{~m} . / \mathrm{m} . \mathrm{y}$. in the turbiditic, bituminous claystones of the Lower Cretaceous Hatteras Formation (Unit IV) (von Rad and Sarti, 1986; van Hinte, Wise, et al., in press).

Site 605 (Fig. 3) is situated on the uppermost continental rise off New Jersey at a water depth of $2194 \mathrm{~m}$. A comparatively thick $(542-\mathrm{m})$ uninterrupted sequence of middle to lower Eocene sediments without turbidites provides the opportunity to study silica diagenesis under a burial depth of 200 to $700 \mathrm{~m}$ in calcareous pelagic sediments rich in siliceous organisms (van Hinte, Wise, et al., in press). Sedimentation rate was high: $56 \mathrm{~m} / \mathrm{m} . \mathrm{y}$. in mid-Eocene Unit II, decreasing downhole to the clayrich nannofossil limestones of upper Paleocene Unit IV.

Site 612 (Fig. 4) was drilled approximately on USGS line 25 , on the middle part of the New Jersey slope at a water depth of $1404 \mathrm{~m}$. The hemipelagic to pelagic deposition was interrupted by a number of unconformities (Site 612 report, this volume; Poag and Low, this volume). However, a sequence of lower Oligocene to lower Eocene nannofossiliferous oozes and chalks, very rich in siliceous organisms, includes the diagenetic boundary between siliceous chalks (Unit II) and porcellanitic nannofossil chalks of lower Eocene Unit III, in Core 36, slightly above the lower/middle Eocene stratigraphic contact (Fig. 4; Plate 2).

These oozes and chalks unconformably overlie clayrich foraminiferal chalks of Maestrichtian age and Campanian dark foraminiferal chalks and pyritic black shales. Sedimentation rate was lower than at Site 605, reaching $25 \mathrm{~m} / \mathrm{m}$.y. in the middle and $35 \mathrm{~m} / \mathrm{m}$.y. in the early Eocene. 


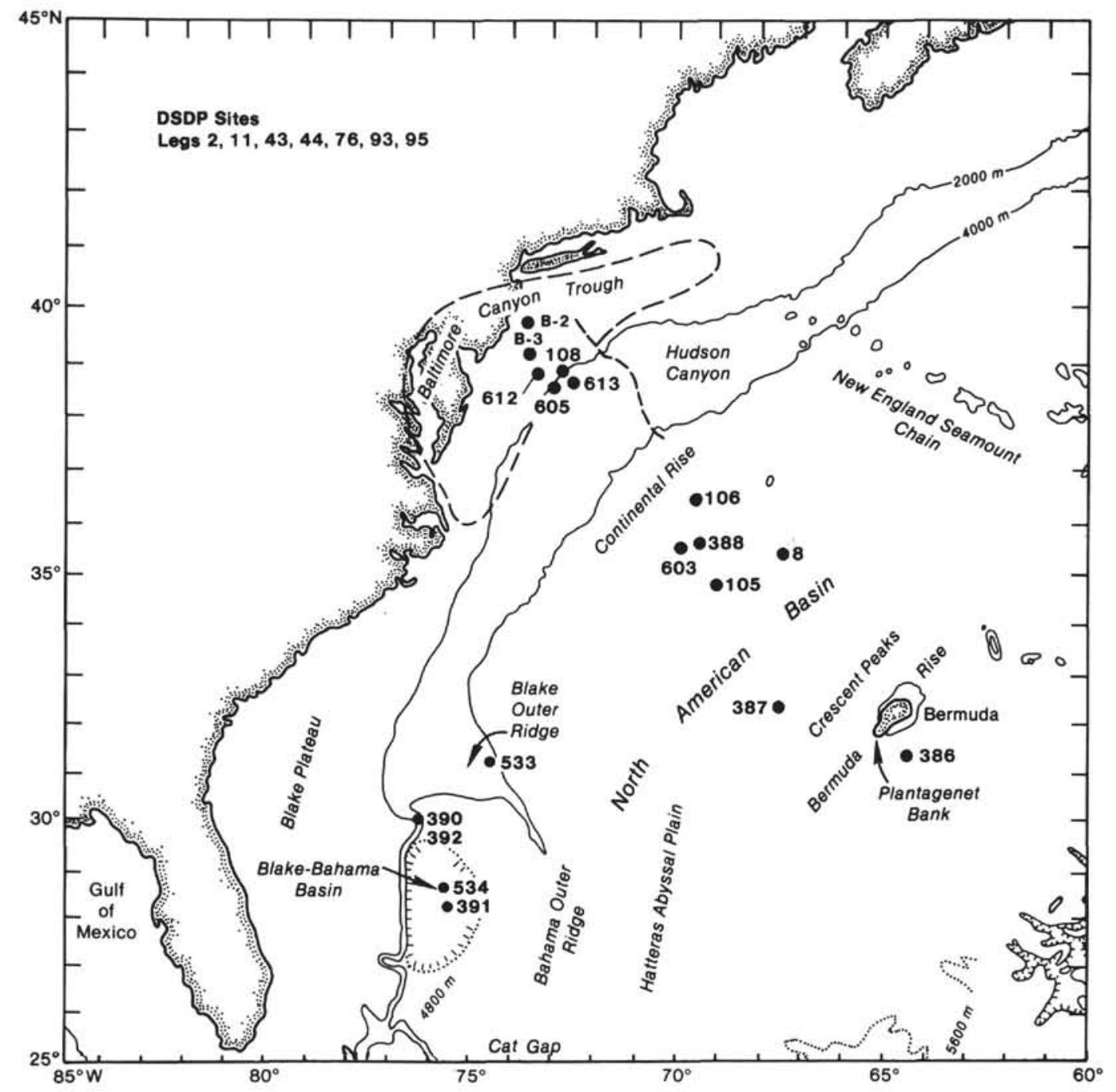

Figure 1. Location map of DSDP Sites 603, 605, 612, and 613, adjacent DSDP sites (from Legs 2, 11, 43, 44, and 76), in the eastern North American Basin and COST B-2 and B-3 wells in the Baltimore Canyon Trough.

The Eocene lithology of Site 612 is identical with that of the nearby continental rise Sites 605 and 613 , and lithostratigraphic units can easily be correlated among the three sites. The lower Eocene sediments, however, are darker and partially laminated (Plate 2 ) and contain more clay, as indicated by $\mathrm{Al}_{2} \mathrm{O}_{3}$ contents up to $12 \%$.

Site 613 (Fig. 5) was drilled about $8 \mathrm{~km}$ northeast of Site 605 , parallel to the strike of the continental rise and at a somewhat greater water depth $(2323 \mathrm{~m})$. At the site, a middle to lower Eocene sequence was encountered that is almost identical to that found at Site 605. It is unconformably overlain by sandy, glauconitic Miocene deposits. Contrary to the coeval sediments of Site 605, the Eocene siliceous nannofossil chalks of Site 613 were repeatedly affected by slumping (Plate 3). Lower and middle Eocene sediments thus are interlayered near the stratigraphic boundary, making it impossible to define an exact contact (see Miller and Hart, this volume). The narrow front of silica diagenesis embraces the base of Core 37 and the top of Core 38 .

An early middle Eocene rhyolitic volcanic ash layer, about $30 \mathrm{~m}$ above this boundary, may make it possible to correlate Site 613 with Site 605 , where a similar ash layer was observed (von Rad and Kreuzer, in press). Sedimentation rates were $35 \mathrm{~m} / \mathrm{m}$.y. in the middle, and $55 \mathrm{~m} / \mathrm{m} . \mathrm{y}$. in the lower Eocene.

\section{METHODS}

For the construction of Figs. 2, 3, 4, 5, 7, and 8, a large number of samples were analyzed by different methods: altogether, we studied 86 thin sections (Plates 4-9), made $\mathrm{C}_{\mathrm{org}} / \mathrm{CaCO}_{3}$ (LECO) determinations on 12 samples, X-ray diffraction analyses on 189 , and chemical analyses on 167 samples. Scanning electron analysis was performed on 7 specimens (Plates 10-12).

\section{SILICA DIAGENESIS}

\section{Sites 605, 612, 613 (Lower Continental Slope and Upper Continental Rise off New Jersey)}

At all three sites the boundary between lithologic Units II and III appears to be a striking lithologic and diagenetic boundary where major compositional characteristics change (Table 1; Figs. 3, 4, 5, and 8; Plate 1, Fig. 1; Plate 2; and Plate 3). 


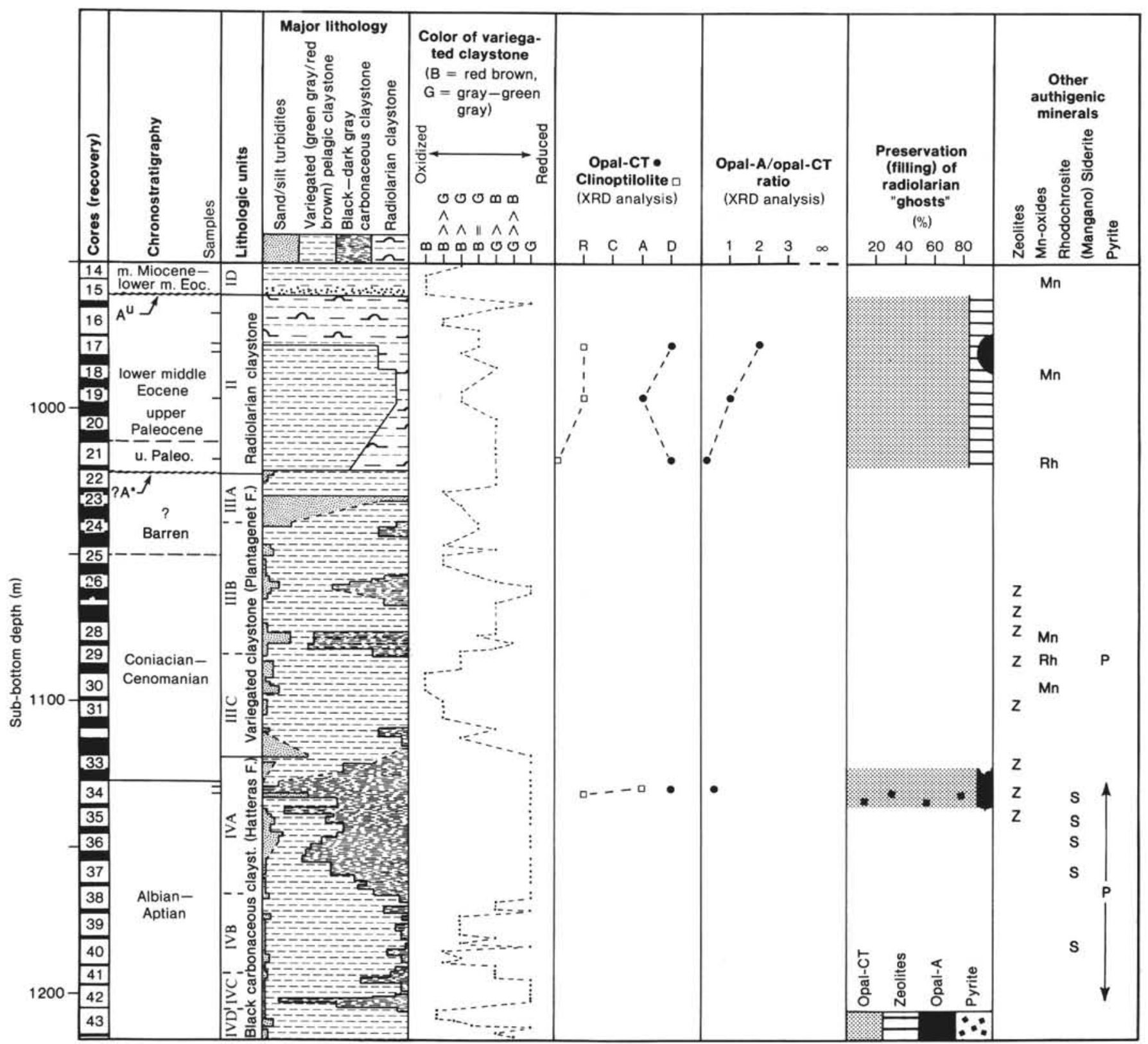

Figure 2. Site 603 lithostratigraphy (Leg 93) (Units ID-IV: mid-Eocene to Aptian) with relevant data regarding silica diagenesis. For X-ray diffraction data, $\mathbf{R}=$ rare, $\mathrm{C}=$ common, $\mathrm{A}=$ abundant, and $\mathrm{D}=$ dominant. Preservation of radiolarians or radiolarian "ghosts" (opal-A versus opalCT) estimated from thin sections. All other data after XRD analyses. Other abbreviations: $\mathrm{Mn}=$ manganese oxides (nodules, etc.); $\mathrm{p}=$ pyrite; $\mathrm{rh}=$ rhodochrosite; $\mathrm{s}=$ (mangano-) siderite; $\mathrm{z}=$ zeolite (clinoptilolite).

The unit boundary marks the diagenetic change from unsilicified or very weakly silicified radiolarian, diatomaceous, clay-bearing nannofossil chalks without opalCT (or opal-A $\gg$ opal-CT), to underlying porcellanitic nannofossil chalks and limestones with opal-CT $\gg$ opal-A. The transition, which in the western North Atlantic causes the widespread seismic reflector $\mathrm{A}^{\mathrm{c}}$ of $\mathrm{Tu}$ cholke and Mountain (1979), is very sharp. Within one core, rock-physical properties change drastically: downhole, bulk density, grain density, and sonic velocity rise, whereas porosity and water content drop to minimum values (Biart, in press; Johns, in press; Wilkens et al., this volume). At Site 612, these physical changes correspond to several layers of porcellanitic limestone nodules in the lowest part of the middle and the upper part of the lower Eocene siliceous porcellanitic chalks. The sharp change in the acoustic velocity explains the observed strong seismic reflection horizon.

At this diagenetic boundary, the siliceous microfossils preserved as opal-A vanish (e.g., at Site 613, in Section 613-38-2, within a depth range of $40 \mathrm{~cm}$ ). According to the stability of their siliceous skeletons, depending mainly on the specific surface area, diatoms were dissolved first, followed by radiolarians, and finally by the most resistant sponge spicules. Apart from the mineralogical change of opal-A to opal-CT and an enhanced calcite diagenesis (pore-filling sparitic cement, replacement of opal-A skeletons; see Plates 6-9), we observed only minor geochemical changes at this important diagenetic boundary. Major elements $(\mathrm{Ca}, \mathrm{Si}, \mathrm{Al})$ show a 


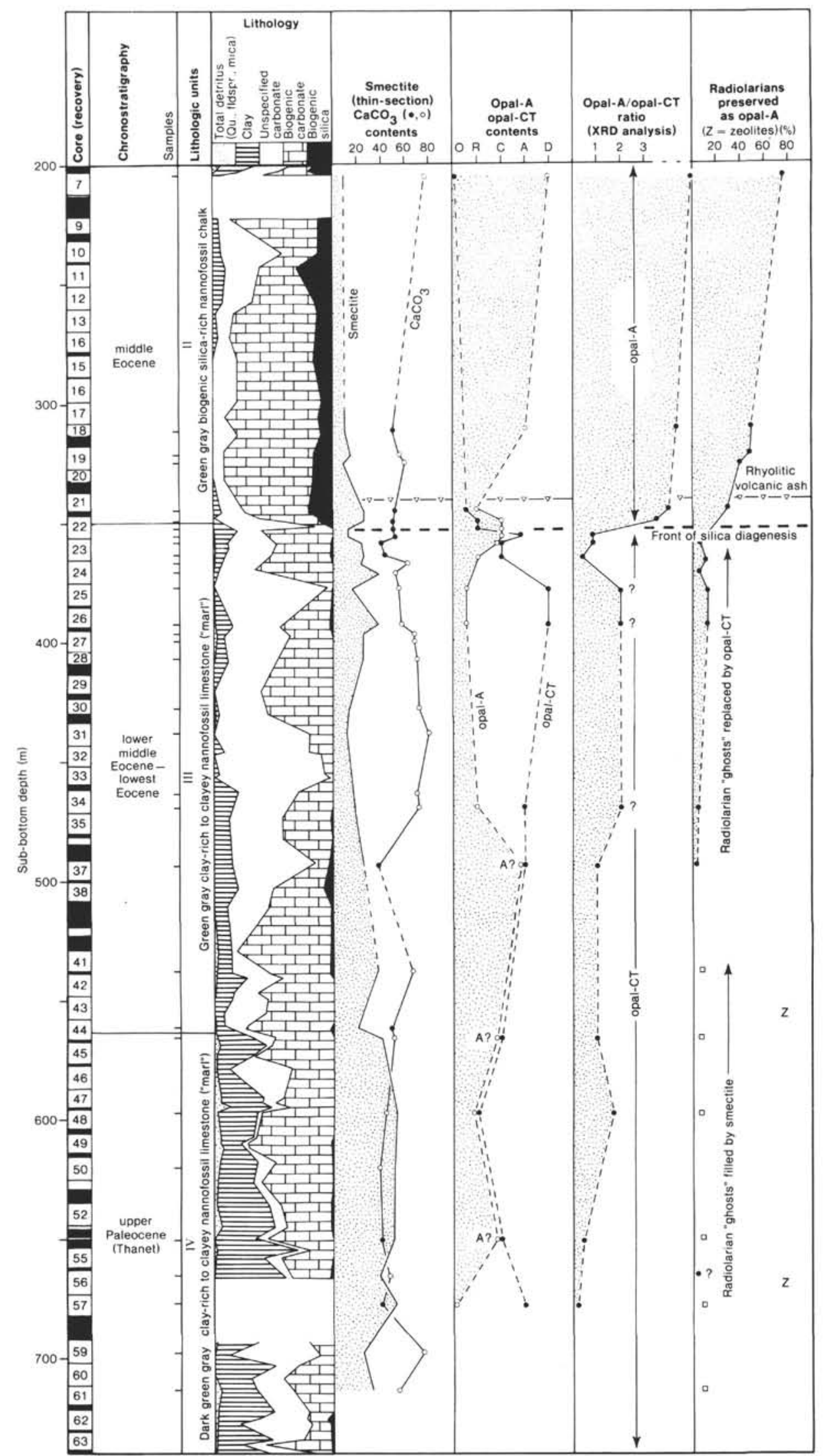

Figure 3. Site 605 lithostratigraphy (Leg 93) (Units II-IV: mid-Eocene to upper Paleocene) with relevant data regarding silica diagenesis. $\mathrm{CaCO}_{3}$ contents estimated from optical analysis ( $\left.{ }^{\circ}\right)$ or measured percentages from LECO carbon determination $(\bullet)$. A ? = X-ray amorphous matter of questionable composition (opal-A less likely). $\square=$ Radiolarian "ghosts" filled by smectite. 


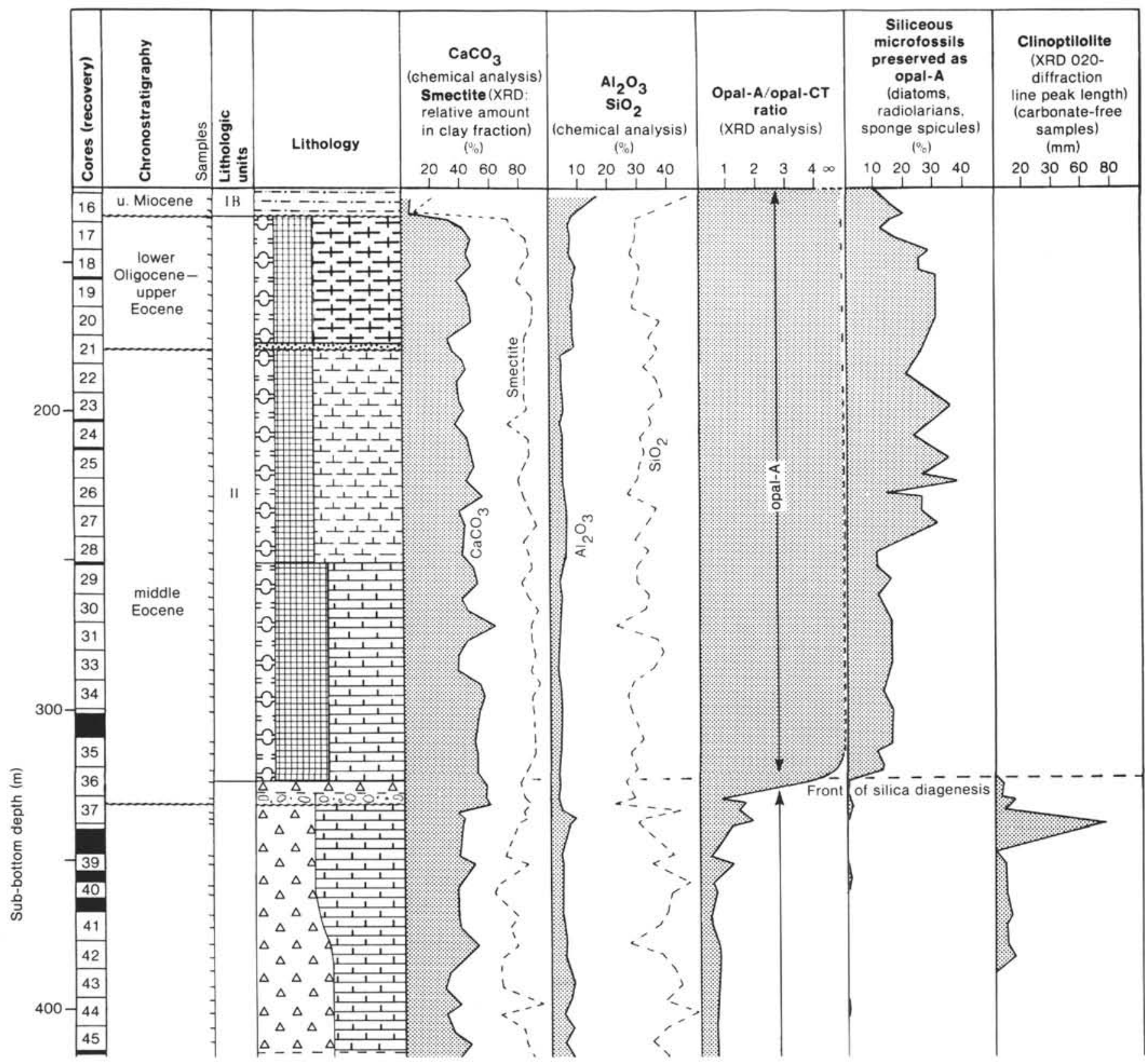

Figure 4. Site 612 lithostratigraphy (Leg 95) (Units IB-V: lower Oligocene to upper Campanian) with relevant data regarding silica diagenesis. CaCO determined by chemical analysis, relative smectite content of total clay mineral fraction analyzed by $\mathrm{XRD} ; \mathrm{Al}_{2} \mathrm{O}_{3}$ and $\mathrm{SiO}_{2}$ determined by chemical analyses; opal-A/opal-CT ratio based on semiquantitative estimation, given XRD analyses; siliceous microfossils preserved as opal-A based on shipboard smear-slide analyses; zeolites, determined by peak length of the clinoptilolite 020-diffraction line.

slight shift to lower $\mathrm{CaCO}_{3}$, higher $\mathrm{Al}_{2} \mathrm{O}_{3}$, and higher $\mathrm{SiO}_{2}$ contents below the diagenetic front (Figs. 4, 5). Simultaneously the smectite percentage in the clay mineral fraction drops slightly at Site 612 (Fig. 4), though the total amount of smectite seems to rise according to thinsection analyses at Site 605 (Fig. 3). This is consistent with the overall higher $\mathrm{Al}_{2} \mathrm{O}_{3}$ contents in the lower Eocene sediments. Clay-mineralogic analyses of Site 612 and 613 specimens (Thein and Schäfer, in prep.) show that at Site 612 the smectite deficit is compensated by illite, which, in the upper part of the lower Eocene, makes up more than $40 \%$ of the $<2-\mu$ m clay mineral fraction.

The importance of this shift in relative and absolute clay content at the diagenetic front is accentuated by the first downhole occurrence of zeolites, mainly clinoptilolite. Clinoptilolite could be detected by X-ray diffraction (XRD) analysis in larger amounts only at Site 612 (Fig. 4), but microscopically it can also generally be observed below the silicification front as pore filling or matrix cement at the two other sites. At Site 612 appreciable amounts appear mainly in the $\mathrm{Al}_{2} \mathrm{O}_{3}$ (clay)-rich horizons in the lower Eocene chalks and especially in the Maestrichtian and Campanian sediments, where sufficient $\mathrm{Al}$, alkaline, and earth-alkaline ions were available in the pore water to form authigenic silicates. Presumably the dissolved silica concentration fell here below that of saturation for opal-CT. This might have been caused in part by smectite neoformation from detrital 


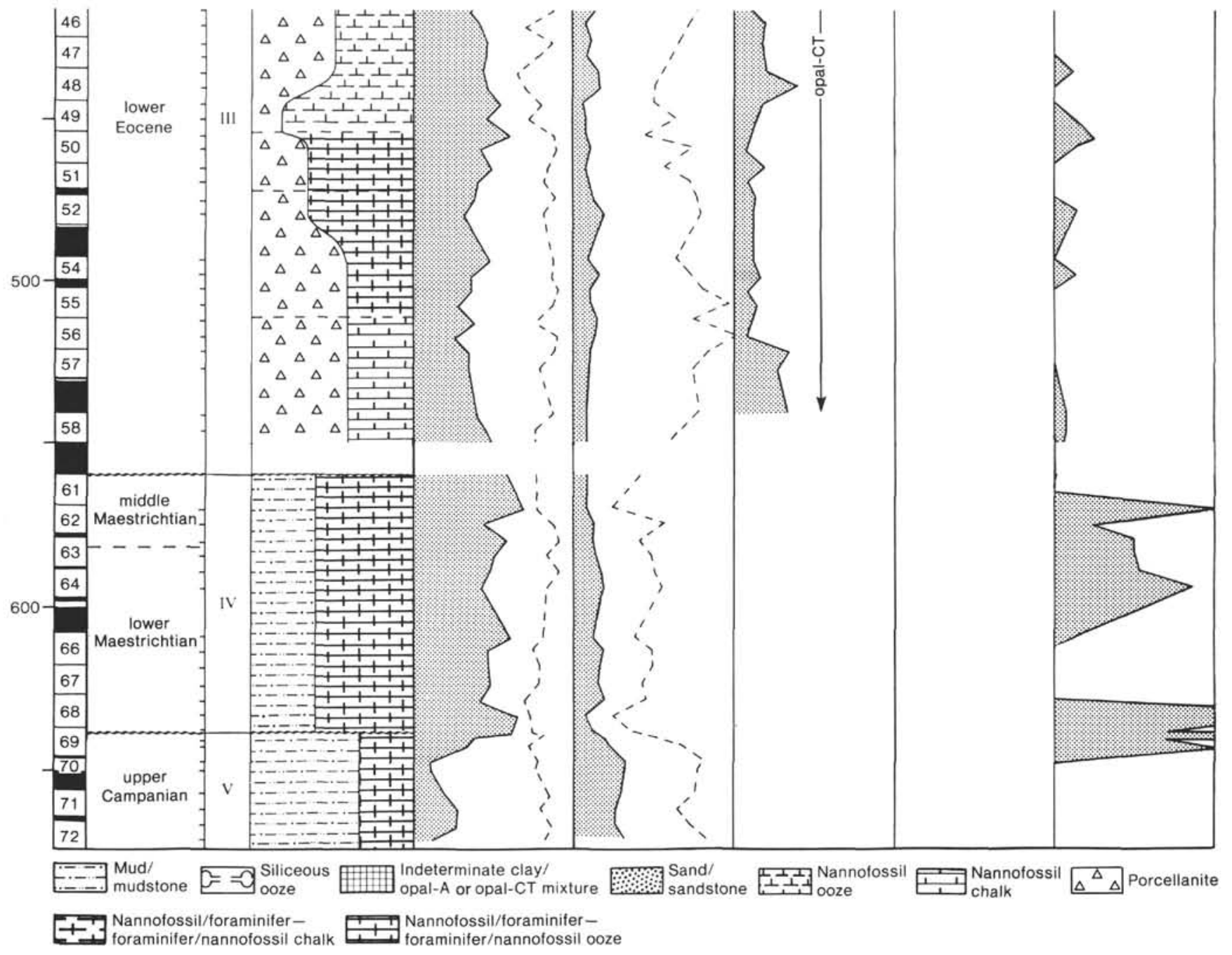

Figure 4 (continued).

clay minerals (illite, kaolinite, etc.). On the other hand, smectite formation seems to have been retarded in the environment of opal-CT formation. A series of XRD analyses crossing the diagenetic front (Fig. 6) shows that both minerals are negatively correlated. The higher the disordered cristobalite peak (opal-CT), the lower is the smectite peak, which becomes successively broader, indicating poor crystallinity. Apparently the complex equilibrium of $\mathrm{Si}, \mathrm{Al}$, and, to a minor degree, $\mathrm{Ca}, \mathrm{Mg}, \mathrm{Na}$, and $\mathrm{K}$ in the interstitial solutions defines whether opal$\mathrm{CT}$, zeolites, and/or smectite is being formed from the source material during diagenesis. Zeolites form in the clay-rich sediments, where the opal-A $\rightarrow$ opal-CT conversion is largely retarded (Kastner et al., 1977). Geochemically these are horizons with minimal $\mathrm{SiO}_{2}$ and maximal $\mathrm{Al}_{2} \mathrm{O}_{3}$ contents (Figs. 4, 5, 8). In the Upper Cretaceous sediments of Site 612 no biogenic silica phases could be detected by XRD, whereas the formation of clinoptilolite is very conspicuous.

\section{Site 603 (Lowermost Continental Rise)}

Due to an upper mid-Eocene to mid-Miocene hiatus, the diagenetically equivalent zone of the unsilicified or weakly silicified biosiliceous chalk Unit II at Sites 605, 612 , and 613 is largely missing at Site 603 . Because the pre-Pleistocene Cenozoic section was deposited below the $\mathrm{CCD}$ at this site, the late Paleocene to mid-Eocene part of Unit III is represented by carbonate-free claystones. They are weakly to moderately silicified (porcellaneous radiolarian claystones to porcellanites; see Plate 4, Figs. 1-4; Plate 5, Figs. 1 and 2). Silicification did not lead to the formation of distinct porcellanite nodules or horizons as at the other sites, either because silica diagenesis was retarded in the clayey impermeable environment and/ or because the initial biosiliceous content of the sediment was not high enough. Opal-CT is abundant to dominant. Almost all radiolarians are dissolved and the "fossil ghosts" filled by opal-CT or, less frequently, by clinoptilolite, if they are not open (secondary porosity?). Clinoptilolite is usually the last-formed mineral, filling fossil pores after opal-CT or forming an interstitial cement (after opal-CT) (Plate 10, Figs. 3 and 4). Traces of radiolarians preserved as opal-A may persist.

In the Aptian to Albian carbonaceous claystones (Unit IV), clinoptilolite may become abundant (Plate 7, Fig. 1; Plate 10, Figs. 3 and 4), as in the Upper Cretaceous marls and shales of Site 612 . 


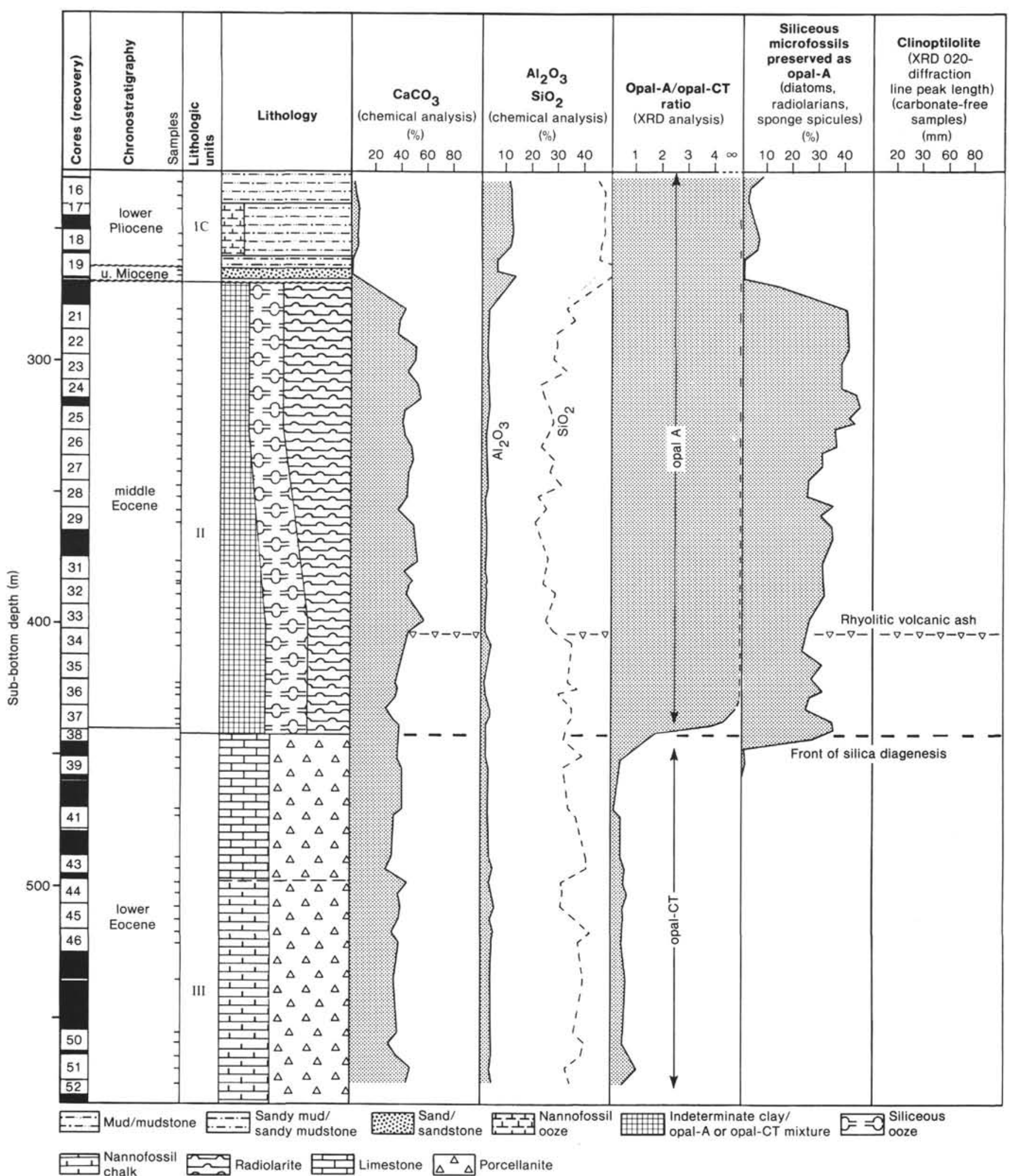

Figure 5. Site 613 lithostratigraphy (Leg 95) (Units IC-III: lower Pliocene to lower Eocene) with relevant data regarding silica diagenesis. For further explanation see Figure 4 caption. 
Table 1. Characteristic compositional and diagenetic changes between lithostratigraphic Units II and III at Site 605 (Fig. 3).

\begin{tabular}{|c|c|c|}
\hline Characteristics & Unit II & Unit III \\
\hline Age & $\begin{array}{l}\text { earliest Eocene to early } \\
\text { middle Eocene }\end{array}$ & "middle Eocene" \\
\hline Burial depth $(\mathrm{m})$ & Ca. $200-350$ & Ca. $350-560$ \\
\hline Color & Light greenish gray $5 G Y 7 / 1$ & $\begin{array}{l}\text { (Darker) greenish gray } 5 G Y 6 / 1 \\
\text { to } 5 / 1 \text { (see Plate 1) }\end{array}$ \\
\hline Consolidation & Nannofossil chalk & Nannofossil limestone to marl \\
\hline Bulk density $\left(\mathrm{g} / \mathrm{cm}^{3}\right)$ & Generally: $1.8-1.5$ & Generally $>1.8$ \\
\hline Porosity (\%) & Generally: $60-45$ & Generally $<45$ \\
\hline Water content $(\%)$ & Generally: $55-40$ & Generally $<40$ \\
\hline $\mathrm{CaCO}_{3}$ content $(\%)$ & $50-75^{b}$ & $\begin{array}{l}\text { Upper part: 50-75; lower part: } \\
\text { decreasing }\end{array}$ \\
\hline Smectite content $(\%)$ & $10-25$ & Increasing (up to $34 \%$ ) \\
\hline Siliceous organisms (\%) (opal-A) & $5-10(-20 ?)$ & Only traces (opal-A?) \\
\hline Opal-CT & None (races in Core 22) & Common to abundant (dominant) \\
\hline Opal-A/opal-CT ratio & $4-50-\infty$ & 1 to zero \\
\hline $\begin{array}{l}\text { Diagenesis of radiolarians and } \\
\text { other siliceous organisms }\end{array}$ & $\begin{array}{l}>50 \% \text { opal-A preserved, } \\
\text { decreasing to } 30 \% \text { near } \\
\text { boundary }\end{array}$ & $\begin{array}{l}\text { Only traces of opal-A preserved } \\
\text { skeletons; radiolarian } \\
\text { "ghosts" filled by opal-CT, } \\
\text { calcite, pyrite, or open }\end{array}$ \\
\hline Ichnofacies (Wetzel, in press) & $\begin{array}{l}\text { Highly bioturbated, highly } \\
\text { diverse association of } \\
\text { lebensspuren; equilib- } \\
\text { rium of sedimentation } \\
\text { and bioturbation }\end{array}$ & $\begin{array}{l}\text { Cores } 33 \text { to } 44 \text { : no individual } \\
\text { burrow structures resolvable, } \\
\text { low diversity, low number of } \\
\text { lebensspuren, biodeforma- } \\
\text { tional association Cores } 23 \text { to } \\
\text { 32: transition of } 11 / 111\end{array}$ \\
\hline
\end{tabular}

${ }^{a} \mathrm{~K}$-Ar age of rhyolitic ash layer (45 Ma) in Sample $605-21 \cdot 2,145-147 \mathrm{~cm}$ indicates slightly younger age b (late Lutetian) than does biostratigraphy (see von Rad and Kreuzer, in press).

$\mathrm{b}^{\mathrm{CaCO}} 3$ content decreasing to around $50 \%$ near Unit $11 / \mathrm{III}$ boundary, maybe because of increasing biosiliceous content.

Phillipsite was not identified by XRD, but was inferred from its crystal habit in thin sections from Hauterivian organic carbon-rich claystones (Plate 4).

A distinct front of opal-A $\rightarrow$ opal-CT transition could not be observed at Site 603. The first measured opal-A/ opal-CT ratios in Core 17 display values around 2, similar to those found below the silica diagenesis front at the other three sites.

The transition from opal-CT to diagenetic quartz can be observed in the recrystallized radiolarians of Valanginian nannofossil limestones (Plate 8, Figs. 3 and 4).

\section{DISCUSSION}

A thorough discussion of silica diagenesis in general and of the situation in the North Atlantic in particular is beyond the scope of this chapter. This topic has been covered in the last few years in some depth by Kastner et al. (1977), Riech and von Rad (1979b), and Kastner (1980). According to these authors, the main variables influencing silica diagenesis in general and the opal-A $\rightarrow$ opalCT transformation that is so distinct between Units II and III at Sites 605, 612, and 613 appear to be:

in situ temperature, influenced by burial depth and regional heat flow;

time (maturation by aging);

host-rock facies (chemical composition of the interstitial solutions and of the host sediment, i.e., carbonate versus clayey-siliceous facies); and paleoenvironment (climate, sea-level stands, pro- ductivity, oceanographic circulation, etc.) influencing the silica source potential.

\section{In Situ Temperature}

According to the in situ temperature measurements at Site 603 (van Hinte, Wise, et al., in press) extrapolated by von Rad and Botz (in press, their fig. 6), the in situ temperature at the sub-bottom depth of $950 \mathrm{~m}$ within the uppermost porcellanitic clays is 40 to $45^{\circ} \mathrm{C}$. Because no in situ temperatures were measured at Sites 605, 612, and 613 , we have to use the values of the nearby COST B-2 and COST B-3 wells (Scholle 1977, 1980), which have a very low temperature gradient of about $26.2^{\circ} \mathrm{C} /$ $\mathrm{km}$. Hence we assume that the in-situ temperatures at the critical silicification front at a sub-bottom depth between 320 and $440 \mathrm{~m}$ range from about 15 to $20^{\circ} \mathrm{C}$. These are very low temperatures for any diagenetic mobilization, because according to Knauth and Epstein (1975), Murata et al. (1977), and Riech and von Rad (1979b), the opal-A $\rightarrow$ opal-CT transformation normally starts at temperatures between about 25 to $50^{\circ} \mathrm{C}$. The Site 603 porcellanites lie within this range, whereas the Sites 605 , 612 , and 613 porcellanitic sediments were apparently formed at considerably lower temperatures.

According to experimental work (Walter and Helgeson, 1977; Fournier, 1983), the solubility of all silica polymorphs increases appreciably with temperature. However, Williams and Crerar (1985) stress that the influence of surface area and particle size on the solubility of opal-A and on the opal-A $\rightarrow$ opal-CT $\rightarrow$ quartz transformation is far more important than temperature. One of the arguments for the temperature-dependent maturation theory explaining the opal-A $\rightarrow$ opal-CT $\rightarrow$ quartz transformation is the progressive diagenetic ordering of the opal-CT lattice structure with increasing burial depth and in situ temperature (Murata and Larson, 1975; von Rad et al., 1978). Williams and Crerar (1985) suggest that the progressive increase of the opal-CT crystallinity with time and depth is a dissolution-reprecipitation mechanism, with tridymite layers preferentially dissolving and cristobalite layers preferentially precipitating. Otsuka (1985) proposed for the silicified sediments of Leg 80 (Northeast Atlantic) that erosion of several hundred meters of sediment at some sites might explain the nearsurface occurrence of silicification and inconsistencies with the expected progressive maturation sequence-an argument that hardly can be applied to the silica diagenesis of the New Jersey Transect drilling sites.

\section{Time}

Riech and von Rad (1979b) showed that the temperature- and age-dependent maturity of the sediment is one of the major factors influencing the opal-A $\rightarrow$ opal-CT transformation: porcellanites were very rare in Pliocene and Miocene sediments in the Atlantic Ocean, became more frequent in pre-Miocene series $(>20 \mathrm{Ma})$, and showed a very marked maximum at around $53 \mathrm{Ma}$ (early to early middle Eocene), where a certain burial depth was usually reached. The rare Pliocene and Pleistocene porcellanites and porcellanitic sediments are associated with diatoms (e.g., Kerguelen Plateau) or reactive volcanogenic material, and elevated heat flow (e.g., Gulf of 


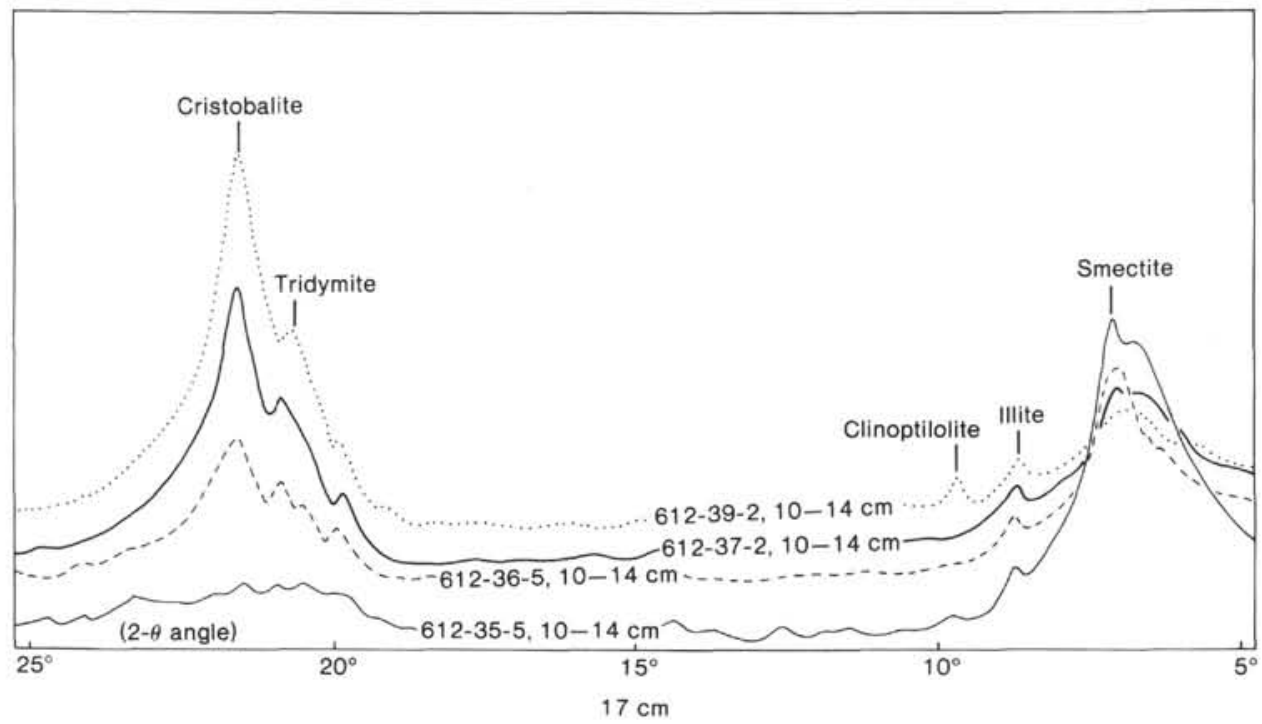

Figure 6. XRD diagrams of Leg 95, Site 612 carbonate-free powder samples taken near the middle/lower Eocene boundary. Opal-CT peaks increase with depth, while simultaneously the smectite peaks decrease and display continuously poorer crystallinity.

California), creating high in situ temperatures even at shallow burial depth. In other cases, the silica is derived from hydrothermal solutions.

With progressive burial, the aging process goes on, via opal-CT to the final quartz stage in mature quartz cherts. Apparently this maturation is very regular in clayey sediments, though highly retarded, whereas in calcareous host rocks it is a more rapid and less depth-dependent process (Otsuka, 1985).

Because of a poor biostratigraphic record at Site 603, it is impossible to date the age of the opal-A/opal-CT contact accurately (about $52 \mathrm{Ma}$ ). At Sites 605, 612, and 613 , however, the "upper front of silica diagenesis" is marked by a rapid downhole increase of the opal-CT contents and downhole decrease of the opal-A/opal-CT ratio. The diagenetic front affects sediments of an age of 49 to $52 \mathrm{~m}$.y. At Site 605 the age of cores 22 and 23 is nannofossil stage CP12 (after Bukry, 1981), corresponding to 50 to $52 \mathrm{Ma}$ (after Berggren et al., 1985); likewise at Site 612 the age of the upper part of Core 36 is CP13b, corresponding to 47 to $49 \mathrm{Ma}$. Here the silicification front lies $8 \mathrm{~m}$ above a hardgroundlike unconformity surface, including a hiatus of $<2-$ m.y. duration between the lower and middle Eocene (Poag and Low, this volume). At Site 613 the age of Cores 37 and 38 is CP12a, or 52 to $52.5 \mathrm{Ma}$ (for a correlation of different Eocene nannofossil age zones with absolute age estimates see von Rad and Kreuzer, in press, their fig. 3).

A 2 to 5 -cm-thick vitreous ash layer of rhyolitic composition occurs about 20 to $40 \mathrm{~m}$ above the silicification front at Sites 605 and 613 (von Rad and Kreuzer, in press). The K-Ar dates for the coarse size fractions of the two ashes of $>45 \mathrm{~m}$.y. support these time estimates.

Thus the youngest porcellanites occur in lower middle to upper lower Eocene strata as elsewhere in the North American Basin (Bermuda Rise Formation of Jansa et al., 1979; Horizon $A^{c}$ of Tucholke and Mountain, 1979).

\section{Host-Rock Facies}

Host-rock composition is of great importance for the diagenetic evolution of biogenic silica into authigenic phases and silicates (Murata and Nakata, 1974; Kastner et al., 1977; Kastner, 1980). Pore-water silica concentration seems to have a major influence on the formation of either opal-CT or quartz. High silica contents in the interstitial solutions favor opal-CT precipitation, whereas concentrations below the equilibrium solubility for opal-CT signal quartz formation (Lancelot, 1973; Keene, 1976; Kastner et al., 1977; Kastner, 1980; Gieskes, 1981; Williams et al., 1985). In siliceous carbonates, comparatively fast formation of porcellanites and subsequent transformation into quartz cherts is the rule (Keene, 1976; Riech and von Rad 1979a, b). Under certain conditions, direct precipitation of chalcedony as a void-filling cement can be observed (Heath and Moberly, 1971; Lancelot, 1973; Riech and von Rad, 1979b). Permeable biogenic sediments rich in siliceous organisms, however, pass the normal diagenetic way of silica transformation from opal-A via an intermediate opal-CT stage to quartz with increasing age and maturity of the sediments. The lower middle to upper lower Eocene siliceous chalks and marls of Sites 605,612 , and 613 have reached the first opalCT stage below the "diagenetic front." Formation of quartz is first observed in the much more deeply buried Lower Cretaceous nannofossil limestones of Site 603.

The presence of associated metal ions such as $\mathrm{Al}^{3+}$, $\mathrm{Mg}^{2+}$, and others (Harder and Flehmig, 1970; Kastner et al., 1977) in clayey sediments and possibly the reduced pore-water mobility largely retard the solution of siliceous skeletons, the migration of dissolved silica, the precipitation of opal-CT, and the further diagenetic development to chalcedony and quartz. It is noteworthy that opal-CT formation in the lower Eocene sediments at Sites 612 and 613 depends largely on the total $\mathrm{SiO}_{2}$ 


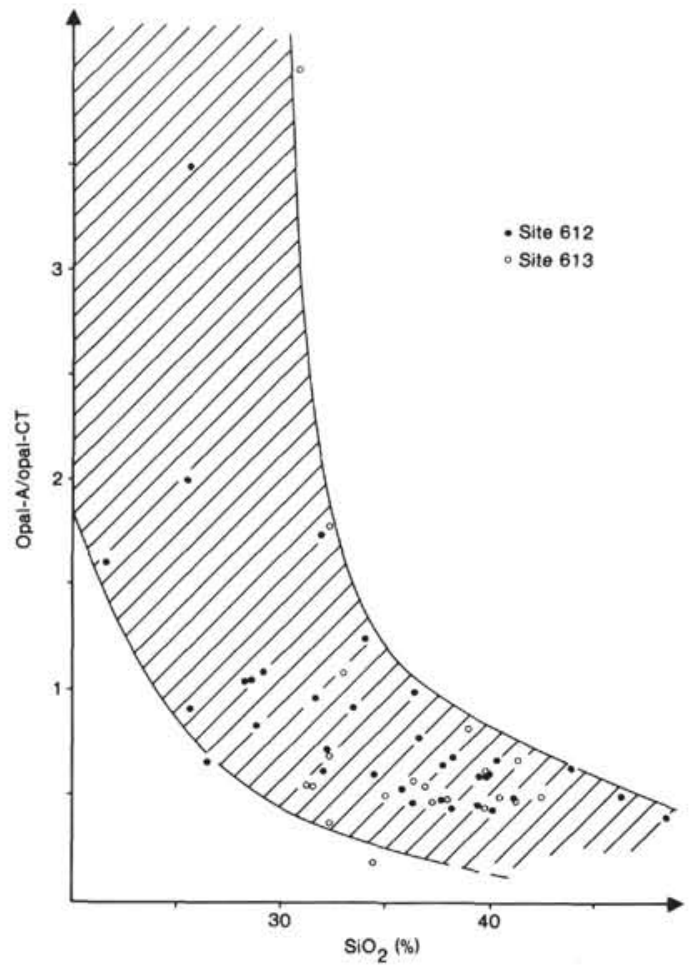

Figure 7. Relationship between the opal-A/opal-CT ratio and total $\mathrm{SiO}_{2}$ content of investigated samples from Sites 612 and 613 .

content of the sediments on the one hand, and on the clay mineral amount on the other. Sediments with low $\mathrm{SiO}_{2}$ concentrations show high opal-A/opal-CT ratios (Fig. 7) and, thus, retarded opal-CT transformation. A weak negative correlation can also be observed between opal-A/opal-CT and $\mathrm{SiO}_{2} / \mathrm{Al}_{2} \mathrm{O}_{3}$ ratios, confirming the postulated retardation of silica diagenesis in clayey host sediments.

The effect of different host rocks is obvious in the New Jersey Transect. Whereas the opal-A $\rightarrow$ opal-CT transformation occurs promptly in the calcareous facies of Sites 605,612 , and 613, this diagenetic step is more retarded in the clayey facies of Site 603, deposited below the CCD. No distinct porcellanitic layers and nodules, as seen below the diagenetic front at Site 612, were formed at this site. (The time-equivalent horizon, however, may be missing because of erosion.) The seismic reflector $A^{c}$ (Tucholke and Mountain, 1979) is missing in the area of Site 603. Whereas Jansa et al. (1979) think that this absence is due to erosion by bottom currents (reflector $\mathrm{A}^{\mathrm{u}}$ cutting below $A^{c}$ ), we suggest that the existence of reflector $\mathrm{A}^{\mathrm{c}}$ strongly depends on the formation of a porcellanite horizon at the top of the porcellanitic chalks. In other words the $\mathrm{A}^{\mathrm{c}}$ reflector does not develop where the opal-A $\rightarrow$ opal-CT conversion is inhibited by strong dilution of the siliceous skeletons with clay (S. Wise, personal communication, 1985; Kastner et al., 1977; Riech and von Rad, 1979b).

According to Riech (1979), clinoptilolite forms at times when opal-CT does not precipitate, such as during periods of increasing or decreasing silica concentrations in the pore water. Apparently, clinoptilolite formation occurs at lower $\mathrm{SiO}_{2}$ concentrations than those necessary for the precipitation of Opal-CT, provided that enough alkaline, earth-alkaline, and $\mathrm{Al}^{3+}$ ions are available. Alrich chalks contain clinoptilolite as a major authigenic silicate, mainly in foraminiferal chambers. In Sample $612-52-2,10-12 \mathrm{~cm}$, clinoptilolite was precipitated first in a clay-rich layer within the generally clay-poor porcellanitic chalks, whereas opal-CT filled the remaining pores. Small-scale changes in Section 612-69-3 stress the importance of the host-rock lithology for the diagenetic development at the Maestrichtian/Campanian boundary. Lower Maestrichtian glauconitic foraminiferal packstones overlie unconformably foraminiferal marls of Campanian age and penetrate downward into burrow structures (Plate 9, Fig. 1). In a stratigraphic distance of less than $10 \mathrm{~cm}$, we observed three types of diagenetic products: (1) in the overlying, permeable porous foraminiferal packstone, foraminifer chambers are all filled with macrocrystalline calcitic (rarely dolomitic) sparite, large clinoptilolite crystals occasionally filling the remaining open pore space (Plate 9, Fig. 2). (2) The same sediment in the burrows developed quite differently during diagenesis: foraminifer chambers are completely filled with microcrystalline clinoptilolite and neoformed smectite (Plate 9, Fig. 3); This suggests rapid crystallization from solutions of higher $\mathrm{SiO}_{2}$ concentrations rich in $\mathrm{Al}^{3+}$. (3) In the surrounding Campanian marls, foraminifer chambers rarely show a rim cement of zeolite or calcite, usually remaining unfilled, due to the poor permeability for circulating pore fluids in the clay-rich sediment (Plate 9, Fig. 4).

At Site 612, the $\mathrm{SiO}_{2} / \mathrm{Al}_{2} \mathrm{O}_{3}$ ratio (i.e., the content of clay) correlates negatively with the amount of zeolites found in the sediment (Fig. 8). The higher the clay content, the more clinoptilolite is generally observed. Below an $\mathrm{SiO}_{2} / \mathrm{Al}_{2} \mathrm{O}_{3}$ ratio of about 4 (clay-rich sediments), clinoptilolite forms in random quantities and can even make up major parts of the sediment. This is the case for the Site 612 Maestrichtian chalks and marls. Biogenous silica is not a necessary prerequisite, as it does not exist in the Maestrichtian chalks. Why certain layers of the Maestrichtian as well as all the underlying Campanian marls are free of zeolites (Fig. 4) is not yet understood. Neither the Al-content in the sediments nor the proportion of any other chemical element changes significantly in the zeolite-free samples of the Maestrichtian. In the Campanian black shales, however, a much higher terrigenous input is inferred from high $\mathrm{Al}-, \mathrm{K}-$, and $\mathrm{Fe}$-contents and rising values of other lithogenous elements (Thein and Schäfer, in prep.). Additionally, high contents of organic matter might prevent zeolite formation. Thus zeolite formation seems to be largely independent of the diagenesis of biogenic silica, as also assumed by Riech (1980) and Otsuka (1985).

\section{Paleoenvironmental Factors}

At all Leg 93 and 95 sites, the stratigraphic level of initial silica diagenesis (uppermost occurrence of opalCT $\gg$ opal-A) lies uniformly in the lowermost middle to uppermost lower Eocene (49-53 Ma). This seems to be more or less independent of the burial depth and hostrock composition, varying from carbonate-rich siliceous oozes at Sites 605,612 , and 613 to carbonate-free sili- 


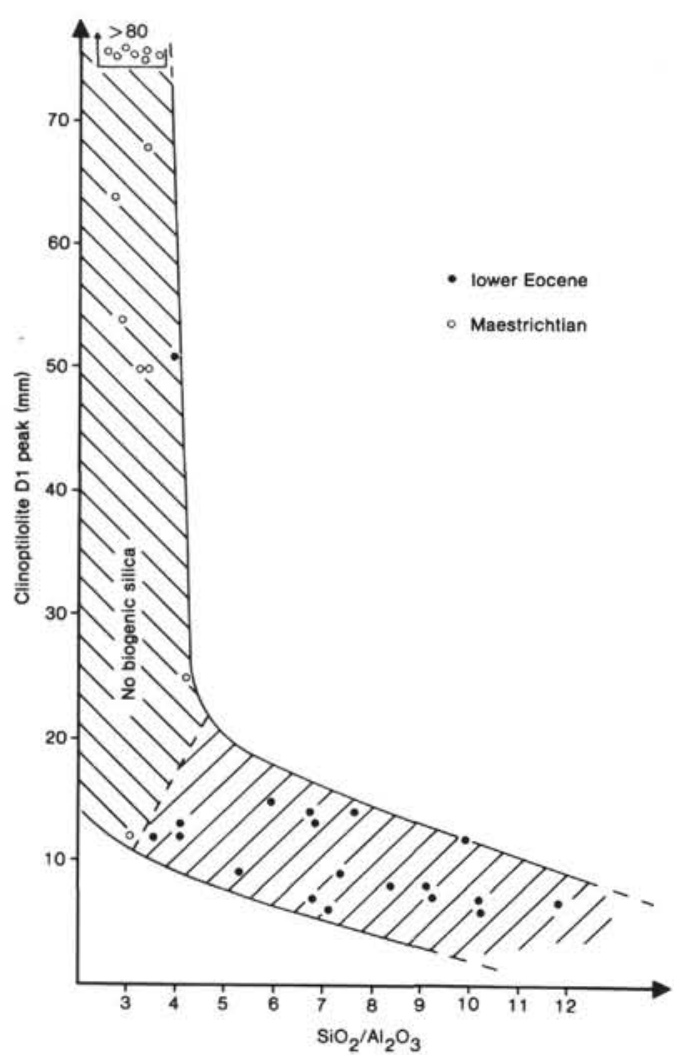

Figure 8. Zeolite (clinoptilolite) abundance, measured as length of the 020-diffraction line ( $=\mathrm{D} 1$ peak), versus $\mathrm{SiO}_{2} / \mathrm{Al}_{2} \mathrm{O}_{3}$ ratio at Site 612.

ceous claystones at Site 603. Jansa et al. (1979), Riech and von Rad (1979b), and Pisciotto (1981) already pointed out the striking maximum occurrence of porcellanites in lower to middle Eocene sediments in the North and South Atlantic Ocean and the adjacent Caribbean Sea and Gulf of Mexico. If we take into account the more recently drilled holes, for the Central and North Atlantic alone, the percentage of DSDP sites at which the uppermost opal-CT occurs in lower middle or lower Eocene sediments is even higher (Fig. 9). Although temperature-, time-, and host-rock-controlled maturation might be important for the diagenetic pathway of biogenic silica, these factors cannot explain the prominent, widespread maximum of lower to middle Eocene porcellanite occurrences. Other environmental parameters must be responsible for the creation of such special sediments in this definite period. It is beyond the scope of this chapter to define these triggering factors, as an evaluation of much more data would be necessary for a regional synthesis. We will, however, enumerate some of these additional factors, although the discussion is speculative.

Climate. Climatic conditions play the ultimate role in weathering processes on the continent. Tropical to subtropical climate in the circum-Atlantic realm, especially during the Paleocene and Eocene (Frakes, 1979), caused intensive chemical weathering at lower latitudes, accompanied by $\mathrm{SiO}_{2}$-mobilization, as can be deduced from Eocene bauxites, laterites, and continental silcretes of many regions: Arkansas, northeast South America, western Central Africa (Valeton, 1983) (Fig. 9). the raised primary influx of dissolved substances (silica, $\mathrm{Al}^{3+}$, nu- trients) and neoformed, unstable silicates (smectites, attapulgite, sepiolite) (Chamley, 1979; Valeton, 1983; Debrabant et al., 1984) from the continents may have been the necessary input to the ocean system to trigger explosive silicoplankton productivity and to create a favorable sediment composition in the oceanic basins, which enhanced the potential for silica diagenesis.

Paleoceanography includes a large number of different parameters (see Emery and Uchupi, 1984, for a compilation): (1) configuration of oceans and continents, opening and barring seaways that connected ocean basins with different water masses; (2) water depth versus CCD; (3) eustatic sea level changes; (4) development of deep-water currents, disturbing stable stratification and oxidizing stagnant basins; (5) salinity, temperature, chemical composition of the seawater, physicochemical conditions in near-bottom and pore water (mainly $\mathrm{pH}$ and Eh values).

Several of these paleoceanographic parameters show major short-term changes ("events") during the period of interest (49-53 Ma): (1) sea level dropped sharply near the end of the early Eocene (52 Ma) (Vail and Hardenbol, 1979) after a widespread transgressive phase in the early Paleogene (thalassocratic time). A coupled climatic deterioration changed the style of weathering on the bordering continents and stopped abruptly the influx of palygorskite and sepiolite, which were replaced in the middle Eocene by kaolinite and smectite (Chamley, 1979). (2) Oxygen isotope data from planktonic and benthic foraminifers provided by Shackleton and Kennett (1975), Shackleton and Boersma (1981), and Kennett (1982) also indicate for the Paleocene and especially the lower Eocene high temperatures for oceanic surface and bottom waters. Drastically decreasing $\delta^{18} 0$ values reflect, as does mineral paragenesis in oceanic sediments, rapidly sinking temperatures as early as the end of the early middle Eocene, which might have been due to first Antarctic glaciations as early as middle Eocene (Shackleton and Boersma, 1981). This might have affected both productivity (surface water masses) and physicochemical conditions of the deep water.

According to Ramsay (1973), Berggren and Hollister (1974), Riech and von Rad (1979b), Jansa et al. (1979), and Tucholke and Mountain (1979), the early and early middle Eocene was a period of unimpeded equatorial circulation between the Tethys, Atlantic, Caribbean, and Pacific oceans. This caused equatorial and coastal upwelling, which provided additional sources of silica and nutrients to the continental influx and increased silicoplankton productivity. Higher sedimentation rates favored the preservation of skeletal opal at the seafloor. A comparatively shallow CCD $(<4500 \mathrm{~m})$ increased the importance of siliceous organisms to deep-sea sedimentation.

\section{CONCLUSIONS}

In general the processes affecting the diagenetic pathway of silica in deep-sea sediments, which are fairly well known from experimental analysis and DSDP observations, were confirmed by our data from Legs 93 and 95 . At the sites studied, the stratigraphically highest diagenetic silica polymorph (opal-CT) appears in lowest middle to uppermost lower Eocene sediments. At Sites 605, 612 , and 613 , a "diagenetic front" separates unaltered 


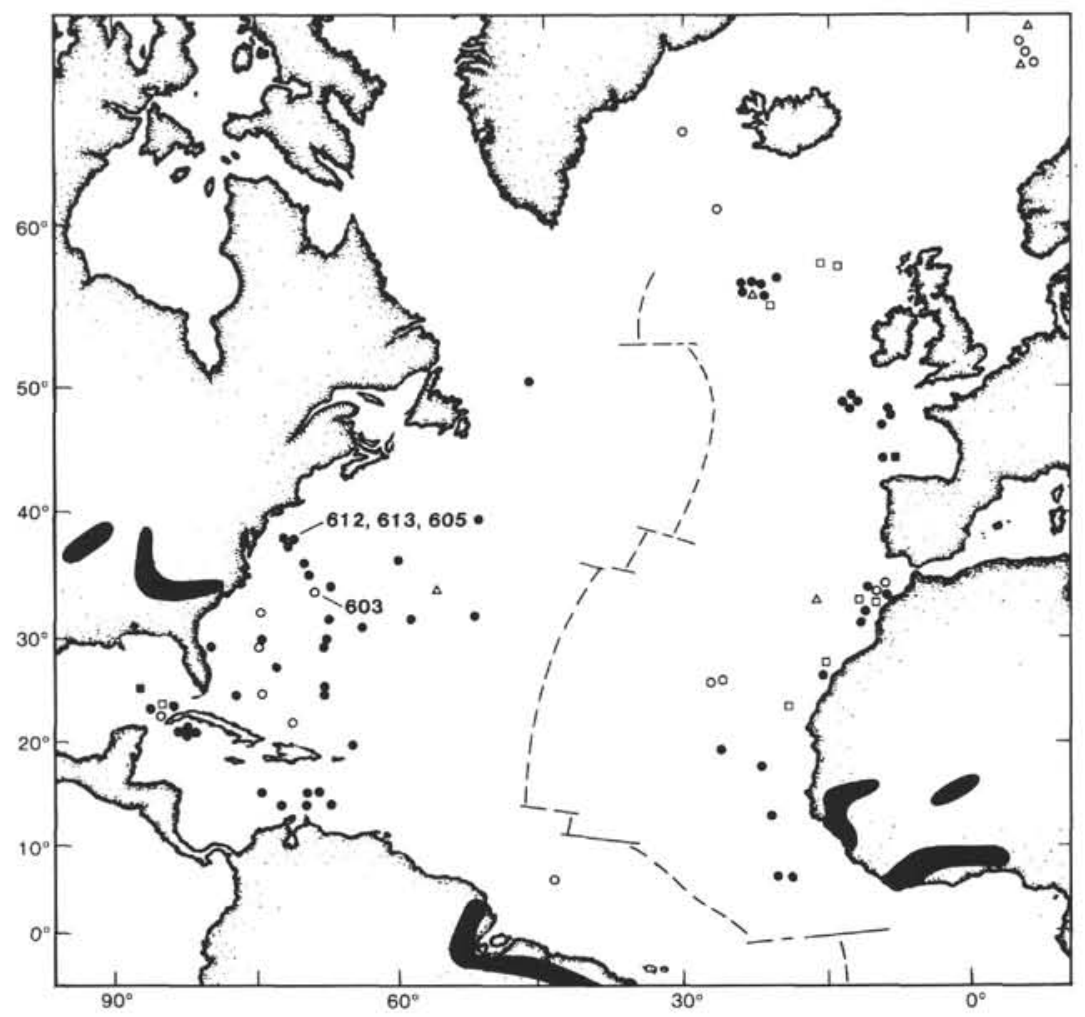

Figure 9. Occurrence of porcellanite in Eocene sediments at all North Atlantic DSDP sites (Legs 1-95). = stratigraphically highest porcellanites in lower to lower middle Eocene sediments; $\bigcirc=$ Eocene sediments missing (hiatus); $\Delta=$ no silicified sediments at site; $\mathbf{\square}=$ youngest porcellanites older than Eocene; $\square=$ youngest porcellanites younger than Eocene (Miocene-Oligocene). Black-shaded areas are Eocene bauxite belts (after Valeton, 1983).

siliceous (opal-A) nannofossil chalks from the underlying porcellanitic (opal-CT) chalks. Because of a hiatus and retarded opal-A $\rightarrow$ opal-CT transformation in clayey sediments deposited below the CCD, no conspicuous silicification front is developed at Site 603.

Dense sampling revealed the sharp character of the diagenetic transition zone ("diagenetic front") at Sites 605,612 , and 613 , which caused the seismic reflector $A^{c}$ in large parts of the western North Atlantic and demonstrates the widespread, more or less synchronous, 49 to 53 m.y.-old "diagenetic event," reflected by the top of the silicified sediments.

Well known factors influencing silica diagenesis are: burial depth, time, and host-rock facies (geochemical composition, $\mathrm{pH}$, Eh, and so on). The conspicuous maximum abundance of porcellanites in the lower middle Eocene to lower Eocene sediments of the northern Atlantic and adjacent oceans, however, suggests superimposed triggering factors for the sudden increase of the silica diagenetic potential, favoring the transformation of biogenic and other silica into authigenic silica (opal$\mathrm{CT}$, quartz) and silicates (zeolites). Paleoenvironmental factors, such as paleoclimate, sea-level fluctuations, oceanic circulation changes, and the influx of unstable silicates from the continent are the controlling parameters for silicoplankton fertility, the preservation of skeletal opal on the seafloor, and the chemistry of the sediment and pore water during this key period of silica diagenesis, all of which should be studied in more detail.

\section{ACKNOWLEDGMENTS}

The authors are very grateful to $\mathrm{H}$. Rösch (Hannover) for contributing the semiquantitative X-ray diffraction analyses of all Sites 603 and 605 samples, to $\mathrm{A}$. Schäfer (Bonn) for executing quantitative clay mineral analyses by XRD, to $\mathrm{H}$. Wehner (Hannover) for the determination of $\mathrm{CaCO}_{3} / \mathrm{C}_{\mathrm{org}}$ with the LECO induction furnace, and to $\mathrm{E}$. Knickrehm (Hannover) for his expert advice at the scanning electron microscope. We thank C. W. Poag (Woods Hole), V. Riech, H. Rösch (Hannover), S. W. Wise (Tallahassee), and two anonymous reviewers for kindly reviewing and improving our manuscript.

\section{REFERENCES}

Berger, W. H., Vincent, E., and Thierstein, H. R., 1981 Deep sea record: major steps in Cenozoic ocean evolution. Soc. Econ. Paleontol Mineral. Spec. Publ., 32:489-504.

Berggren, W. A., and Hollister, C. D., 1974. Paleogeography, paleobiography, and the history of circulation in the Atlantic Ocean. In Hay, H. W. (Ed.), Studies in Paleo-oceanography. Soc. Econ. Paleontol. Mineral. Spec. Publ., 20:126-186.

Berggren, W. A., Kent, D. V., Flynn, J., and Van Couvering, J., 1985. Cenozoic geochronology. Geol. Soc. Am. Bull., 96:1407-1418.

Biart, B. N. M., in press. Physical properties modeling and seismic stratigraphy at Deep Sea Drilling Project Leg 93 sites in the western North Atlantic. In van Hinte, J. E., Wise, S. W., Jr., et al., Init. Repts. DSDP, 93, Pt. 1: Washington (U.S. Govt. Printing Office).

Bukry, D., 1981. Cenozoic coccoliths from Deep Sea Drilling Project. Soc. Econ. Paleontol. Mineral. Spec. Publ., 32:335-353.

Chamley, H., 1979. North Atlantic clay sedimentation and paleoenvironment since the Late Jurassic. In Talwani, M., Hay, H. W., and Ryan, W. B. F. (Eds.), Deep Drilling Results in the Atlantic Ocean: Continental Margins and Paleoenvironment. Am. Geophys. Union, Maurice Ewing Ser., 3:342-361. 
Debrabant, P., Chamley, H., and Foulon, J., 1984. Paleoenvironmental implications of mineralogical and geochemical data in the Western Florida Straits (Leg 77, Deep Sea Drilling Project). In Buffler, R. T., Schlager, W., et al., Init. Repts. DSDP, 77: Washington (U.S. Govt. Printing Office), 377-396.

Emery, K. O., and Uchupi, E., 1984. The Geology of the Atlantic Ocean: New York, Berlin, Heidelberg, Tokyo (Springer-Verlag).

Flörke, O. W., Hollmann, R., von Rad, U., and Rösch, H., 1976. Intergrowth and twinning in opal-CT lepispheres. Contrib. Mineral. Petr., 58:235-242.

Fournier, R. O., 1983. A method of calculating quartz solubilities in aqueous sodium chloride solutions. Geochim. Cosmochim. Acta, 47:579-586.

Frakes, L. A., 1979. Climates Throughout Geologic Time: Amsterdam (Elsevier).

Gieskes, J. M., 1981. Deep Sea Drilling interstitial water studies: implications for chemical alteration of the oceanic crust, layers I and II. Soc. Econ. Paleontol. Mineral. Spec. Publ., 32:149-167.

Hardenbol, J., and Bergren, W. H., 1978. A new Paleogene timescale. In Cohee, G. V., Glaessner, M. F., and Hedberg, H. D. (Eds.), Contributions to the Geologic Time Scale. Studies in Geology, Am. Assoc. Petr. Geol., 6:213-234.

Harder, H., and Flehmig, W., 1970. Quarzsynthese bei tiefen Temperaturen. Geochim. Cosmochim. Acta, 34:295-305.

Heath, G. R., and Moberly, R., 1971. Cherts from the Western Pacific, Leg 7, Deep Sea Drilling Project. In Winterer, E. L., Riedel, W. R., et al., Init. Repts. DSDP, 7, Pt. 2: Washington (U.S. Govt. Printing Office), 991-1008.

Jansa, L. F., Enos, P., Tucholke, B. E., Gradstein, F. M., and Sheridan, R. E., 1979. Mesozoic-Cenozoic sedimentary formations of the North American Basin; western North Atlantic. In Talwani, M., Hay, H. W., and Ryan, W. B. F. (Eds.), Deep Drilling Results in the Atlantic Ocean: Continental Margins and Paleoenvironment. Am. Geophys. Union, Maurice Ewing Ser., 3:58-86.

Johns, M. W., in press. Consolidation and permeability characteristics of sediments from Deep Sea Drilling Project Leg 93, Sites 603 and 604. In van Hinte, J. E., Wise, S. W., Jr., et al., Init. Repts. $D S D P, 93$ : Washington (U.S. Govt. Printing Office).

Kastner, M., 1980. Authigenic silicates in deep-sea sediments: formation and diagenesis. The Sea, 7:915-980.

Kastner, M., Keene, J. B., and Gieskes, J. M., 1977. Diagenesis of siliceous oozes. I. Chemical controls on the rate of opal-A to opal-CT transformation-an experimental study. Geochim. Cosmochim. Acta, 47:1041-1059.

Keene, J. B., 1976. Distribution, mineralogy and petrography of biogenic and authigenic silica in the Pacific Basin [Ph.D. thesis]. Scripps Institution of Oceanography, University of California, San Diego.

Kennett, J. P., 1982. Marine Geology: Englewood Cliffs, New Jersey (Prentice-Hall).

Knauth, L. P., and Epstein, S., 1975. Hydrogen and oxygen isotope ratios in silica from the JOIDES Deep Sea Drilling Project. Earth Planet Sci. Lett., 25:1-10.

Lancelot, Y., 1973. Chert and silica diagenesis in sediments from the Central Pacific. In Winterer, E. L., Ewing, J. I., et al., Init. Repts. DSDP, 17: Washington (U.S. Govt. Printing Office), 377-405.

Murata, K. J., Friedman, I., and Gleason, J. D., 1977. Oxygen isotope relations between diagenetic silica minerals in Monterey shale Temblor Range, California. Am. J. Sci., 227:259-272.

Murata, K. J., and Larson, P. R., 1975. Diagenesis of Miocene siliceous shales, Temblor Range, California. J. Res. U.S. Geol. Surv. $3(5): 553-566$.

Murata, K. J., and Nakata, J. K., 1974. Cristobalite stage in the diagenesis of diatomaceous shale. Science, 186:567-568.

Otsuka, K., 1985. Silicified sediments and silica diagenesis in the Goban Spur area of the Northeast Atlantic, Leg 80. In Graciansky, P. C. de, Poag, C. W., et al., Init. Repts. DSDP, 80: Washington (U.S. Govt. Printing Office), 1081-1099.

Pisciotto, K. A., 1981. Distribution, thermal histories, isotopic compositions and reflection characteristics of siliceous rock recovered by the Deep Sea Drilling Project. Soc. Econ. Paleontol. Mineral. Spec. Publ., 32:129-147.

Ramsay, A. T. S., 1973. A history of organic siliceous sediments in the oceans. In Hughes, N. F. (Ed.), Spec. Paper in Paleontology. Paleontol. Assoc. London, 12:199-234.
Riech, V., 1979. Diagenesis of silica, zeolites and phyllosilicates at Sites 397 and 398. In von Rad, U., Ryan, W. B. F., et al., Init. Repts. DSDP, 47: Washington (U.S. Govt. Printing Office), 741759.

1980. Diagenesis of siliceous sediments, porcellanites and cherts of the Moroccan Basin, Deep Sea Drilling Project Sites 370, 415 and 416. In Lancelot, Y., Winterer, E. L., et al., Init. Repts. $D S D P, 50$ : Washington (U.S. Govt. Printing Office), 725-731.

Riech, V., and von Rad, U., 1979a. Eocene porcellanites and Early Cretaceous cherts from the western North Atlantic Basin. In Tucholke, B. E., Vogt, P. R., et al., Init. Repts. DSDP, 43: Washington (U.S. Govt. Printing Office), 437-455.

1979b. Silica diagenesis in the Atlantic Ocean: diagenetic potential and transformations. In Talwani, M., Hay, H. W., and Ryan, W. B. F. (Eds.), Deep Drilling Results in the Atlantic Ocean: Continental Margins and Paleoenvironment. Am. Geophys. Union, Maurice Ewing Ser., 3:315-340.

Scholle, P. A. (Ed.), 1977. Geological studies on the COST No. B-2 well, United States Mid-Atlantic outer continental shelf area. U.S. Geol. Surv. Circ., Vol. 750.

1980. Geological studies on the COST No. B-3 well, United States Mid-Atlantic continental slope area. U.S. Geol. Surv. Circ., Vol. 833.

Shackleton, N. J., and Boersma, A., 1981. The climate of the Eocene ocean. J. Geol. Soc. London, 138:153-157.

Shackleton, N. J., and Kennett, J. P., 1975. Paleotemperature of the Cenozoic and the initiation of Antarctic glaciation: oxygen and carbon isotopic analyses in DSDP Sites 277, 279, and 281. In Kennett, J. P., Houtz, R. E., et al., Init. Repts, DSDP, 29: Washington (U.S. Govt. Printing Office), 743-755.

Tucholke, B. E., and Mountain, G. S., 1979. Seismic stratigraphy, lithostratigraphy and paleosedimentation patterns in the North American Basin. In Talwani, M., Hay, H. W., and Ryan, W. B. F. (Eds.), Deep Drilling Results in the Atlantic Ocean: Continental Margins and Paleoenvironment. Am. Geophys. Union, Maurice Ewing Ser., 3:58-86.

Vail, P. R., and Hardenbol, J., 1979. Sea-level changes during the Tertiary. Oceanus, 22:71-79.

Valeton, I., 1983. Klimaperioden lateritischer Verwitterung und ihr Abbild in den synchronen Sedimentationsräumen. Z. Dt. Geol. Ges., 134:413-452.

van Hinte, J. E., Wise, S. W., Jr., et al., in press. Init. Repts. DSDP: 93: Washington (U.S. Govt. Printing Office).

von Rad, U., and Botz, R., in press. Authigenic Fe-Mn carbonates in the Cretaceous and Tertiary sediments of the continental rise off eastern North America, Deep Sea Drilling Project Site 603. In van Hinte, J. E., Wise, S. W., Jr., et al., Init Repts. DSDP, 93, Pt. 2: Washington (U.S. Govt. Printing Office).

von Rad, U., and Kreuzer, H., in press. Composition, K-Ar dates and origin of a mid-Eocene rhyolitic ash layer at Deep Sea Drilling Project Sites 605 and 613, and New Jersey Transect, Legs 93 and 95. In van Hinte, J. E., Wise, S. W., Jr., et al., Init. Repts. DSDP, 93, Pt. 2: Washington (U.S. Govt. Printing Office).

von Rad, U., Riech, V., and Rösch, H., 1978. Silica diagenesis in continental margin sediments off Northwest Africa. In Lancelot, Y., Seibold, E., et al., Init. Repts. DSDP, 41: Washington (U.S. Govt. Printing Office), 849-905.

von Rad, U., and Sarti, M., 1986. Early Cretaceous events in the evolution of the eastern and western North Atlantic continental margins. Geol. Rundschau, 75:139-158.

Walther, J. V., and Helgeson, H. C., 1977. Calculation of the thermal dynamic properties of aqueous silica and the solubility of quartz and its polymorphs at higher pressures and temperatures. Am. J. Sci., 277:1315-1351.

Wetzel, A. in press. Ichnofabrics in Eocene to Maestrichtian sediments from Deep Sea Drilling Project Site 605, off the New Jersey coast. In van Hinte, J. E., Wise, S. W., Jr., et al., Init. Repts. DSDP, 93, Pt. 2: Washington (U.S. Govt. Printing Office).

Williams, L. A., and Crerar, D. A., 1985. Silica diagenesis II. General mechanisms. J. Sed. Petrol., 55:312-321.

Williams, L. A., Parks, G. A., and Crerar, D. A., 1985. Silica diagenesis I. Solubility controls. J. Sed. Petrol., 55:301-311.

Date of Initial Receipt: 30 September 1985

Date of Acceptance: 25 August 1986 


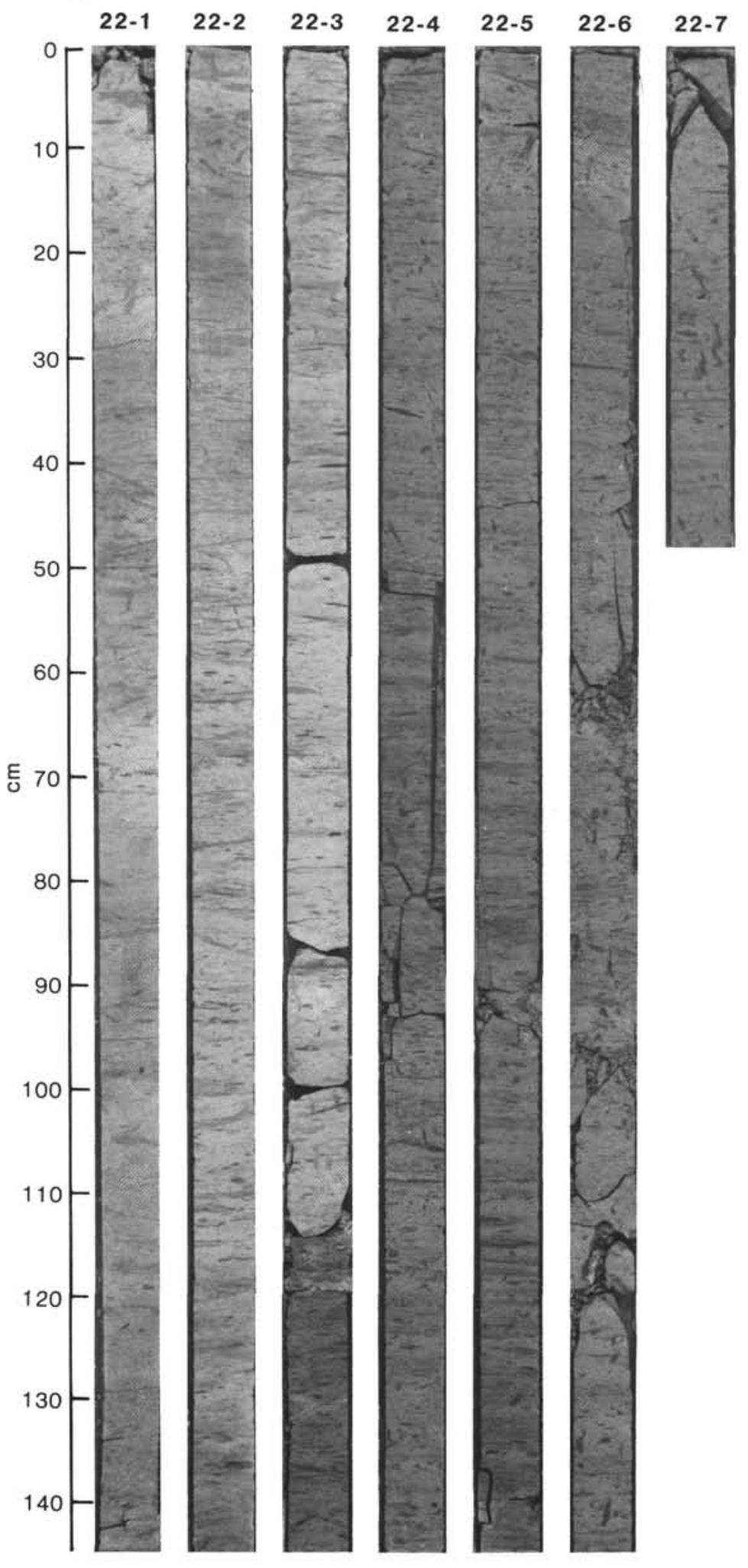

2
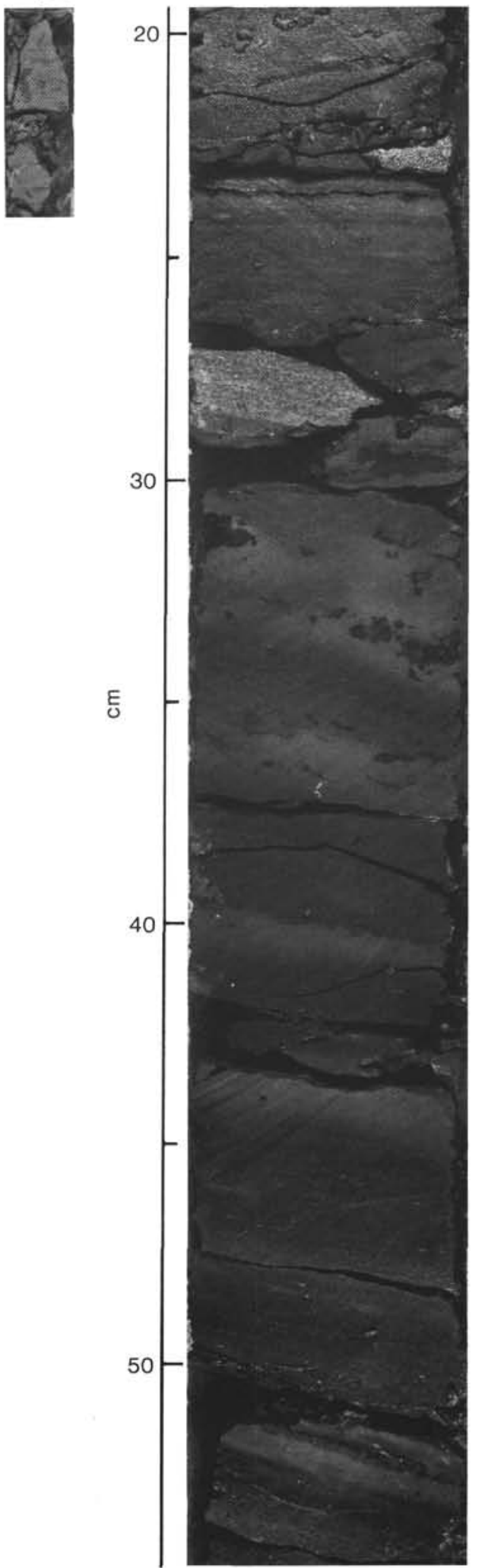

Plate 1. Shipboard core photos of Eocene silicified sediments of Sites 603 and 605 . 1. Boundary between stratigraphic Units II (light greenish gray biogenic silica-rich nannofossil chalk) and III (greenish gray nannofossil marlstone) at Site 605 at about $350 \mathrm{~m}$ sub-bottom depth (a distinct color change occurs at Core 605-22-3, $114 \mathrm{~cm}$ ). 2. Section 603B-18-1 (Unit II, radiolarian claystone). Color banding (olive yellow-yellowish brown) indicates change between reducing and oxidizing conditions and manganese crusts, overlying light yellowish brown claystones (e.g., at 27 and $53 \mathrm{~cm}$ ) and $\mathrm{Mn}$ oxide-filled nodules and lenses (e.g., at $34 \mathrm{~cm}$ ). 
1

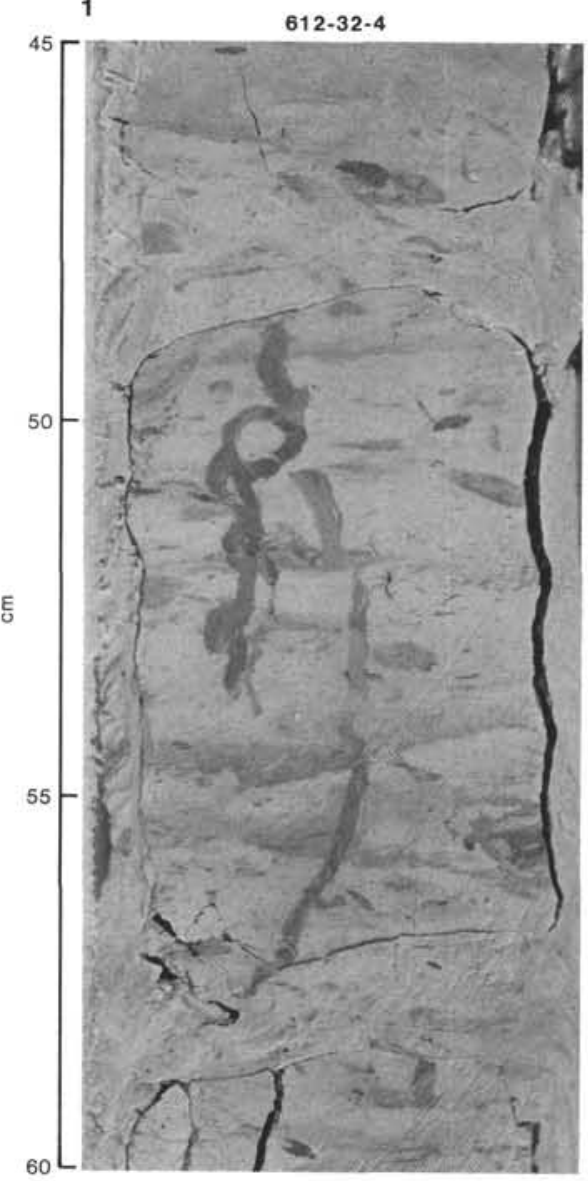

2

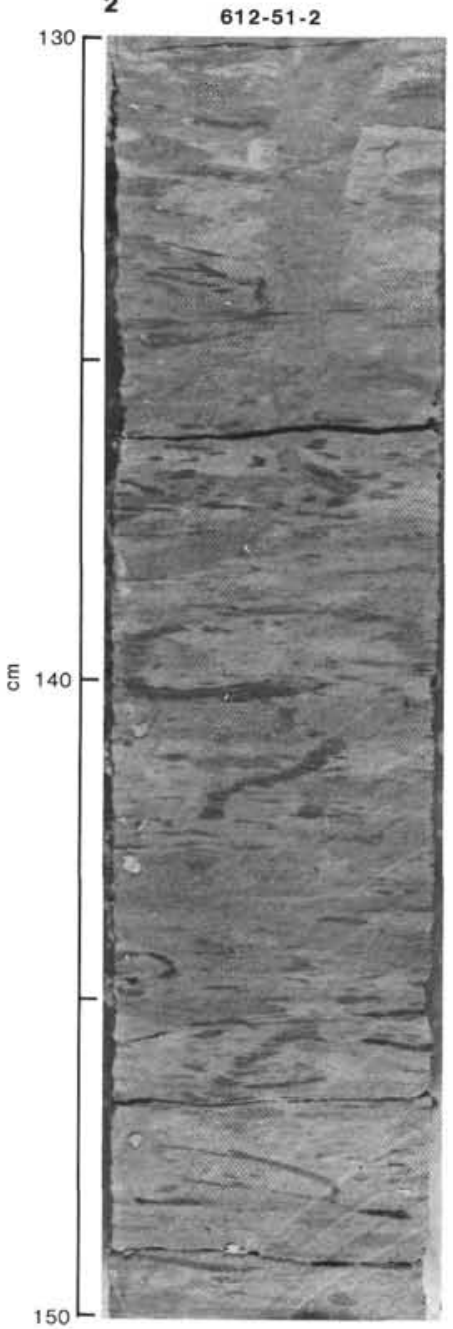

3

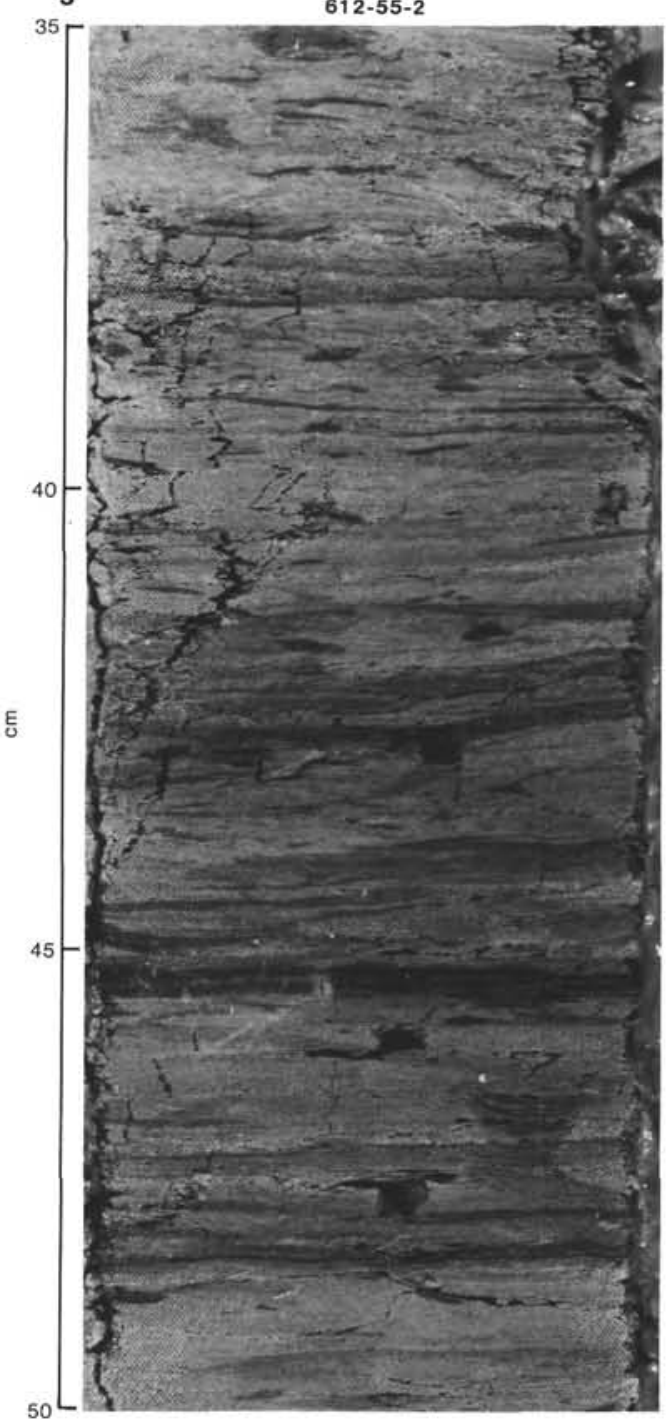

Plate 2. Shipboard core photos of Site 612 Eocene sediments. 1. Light greenish gray (5G 8/1) bioturbated siliceous nannofossil chalk of early middle Eocene age. Sample $612-32-4,45-60 \mathrm{~cm}$. 2. Grayish green to olive gray porcellaneous nannofossil chalk of early Eocene age. Compaction due to diagenetic silica and carbonate dissolution is much stronger that in middle Eocene sediments. Burrows are highly flattened. Sample $612-51-2,130-150 \mathrm{~cm}$. 3. Laminated to thin-bedded porcellaneous chalk (olive gray to light olive gray). Section is part of a sequence of rhythmically alternating massive and laminated sediments. Sample 612-55-2, 35-50 cm (lower Eocene). 
1

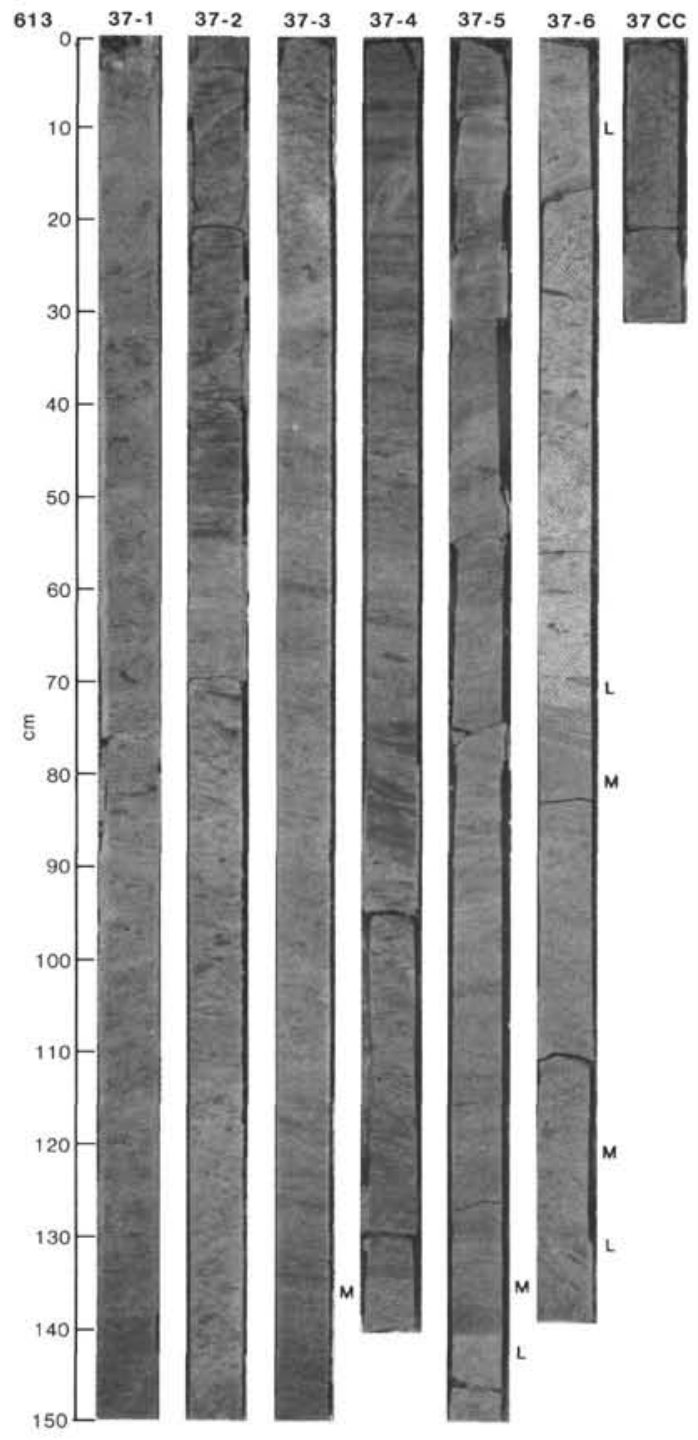

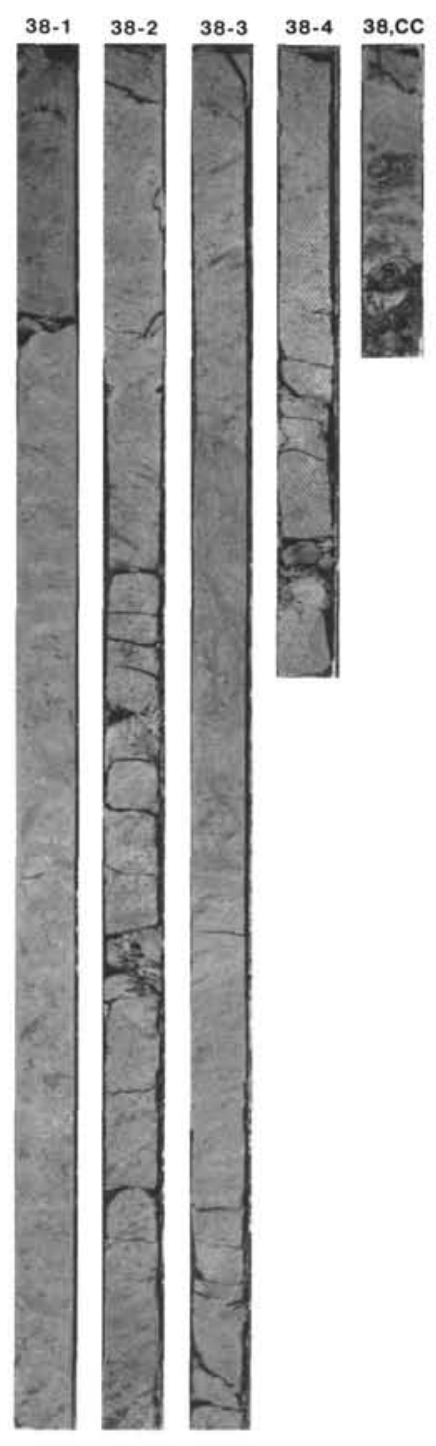

Plate 3. Shipboard core photos of Site 613 Eocene sediments. 1. Boundary between lithologic Units II and III at Site 613 , Cores 37 and 38 . Shearing and folding due to slumping activity repeats the lower $(\mathrm{L})$ and middle $(\mathrm{M})$ Eocene sediments several times. The biostratigraphic boundary lies at the bottom of Core 37. Opal-CT is dominant below Section 613-38-2. Limestone beds and porcellaneous layers are brecciated by drilling. 2. Detail of a slumped part of lowest middle Eocene siliceous nannofossil chalk. Small-scale chevron faults and folds are produced in a thin-bedded, bioturbated sediment by slow downslope creep of ooze. Sample 613-37-2, 70-85 cm. 

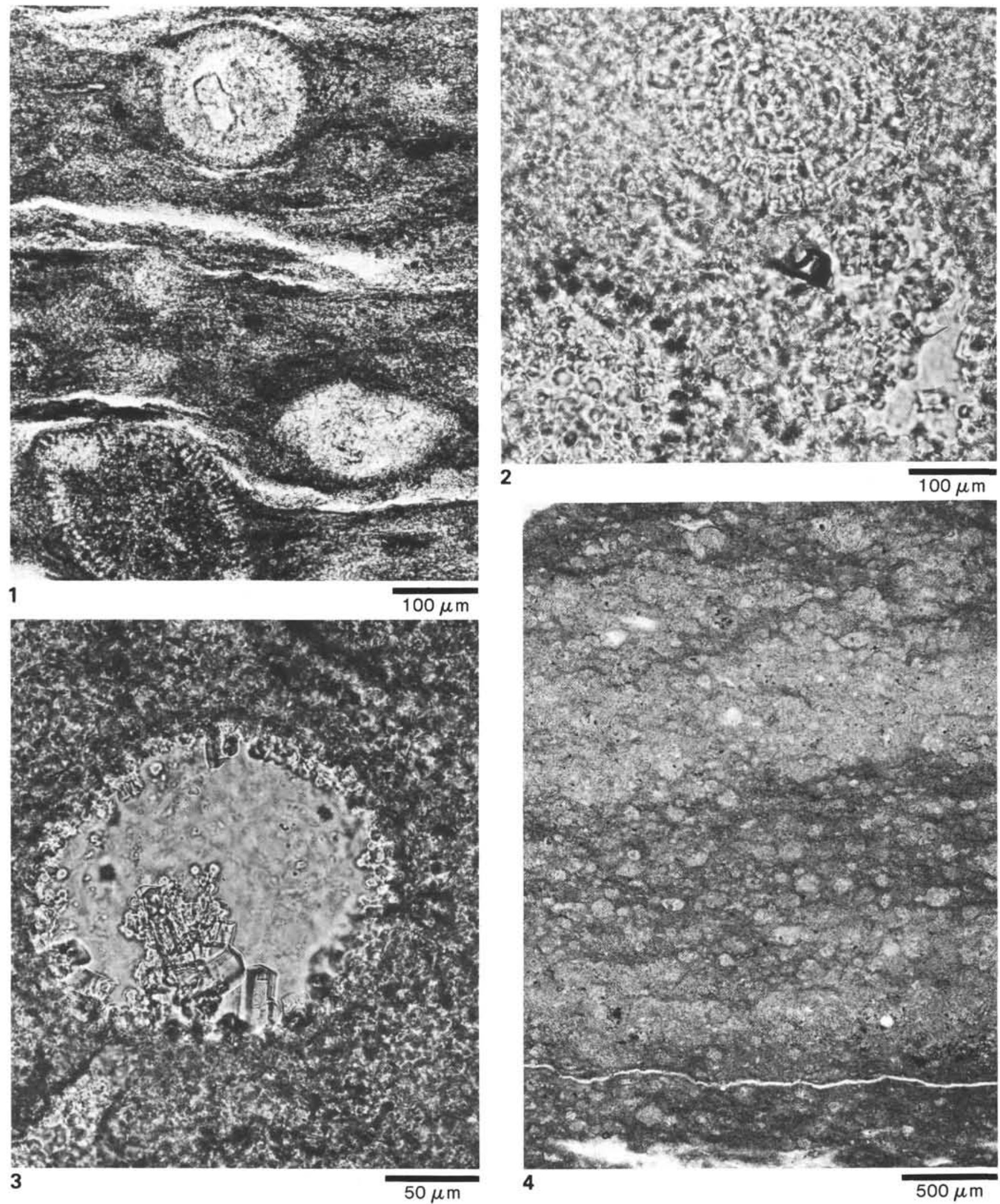

Plate 4. Silica diagenesis at Site 603 (photomicrographs). 1. Laminated radiolarian claystone with radiolarian "ghosts" filled by opal-CT lepispheres (and clinoptilolite crystals). Sample 603B-17-3, 144-145 cm (Eocene). 2. Radiolarian porcellanite with opal-CT replaced and filled radiolarian "ghost." Note lepisphere-type fabric and clinoptilolite in matrix. Sample 603B-17-4, 70-72 cm (Eocene). 3. Same sample as in Figure 2, with radiolarian "ghosts"-clinoptilolite growing into open pore space; opal-CT in matrix. 4. Porcellaneous radiolarian claystone. Light-colored bands consist of clinoptilolite-bearing porcellanite; dark layers, of less silicified radiolarian claystone. Sample 603B-19-2, 131-134 cm (Eocene). 

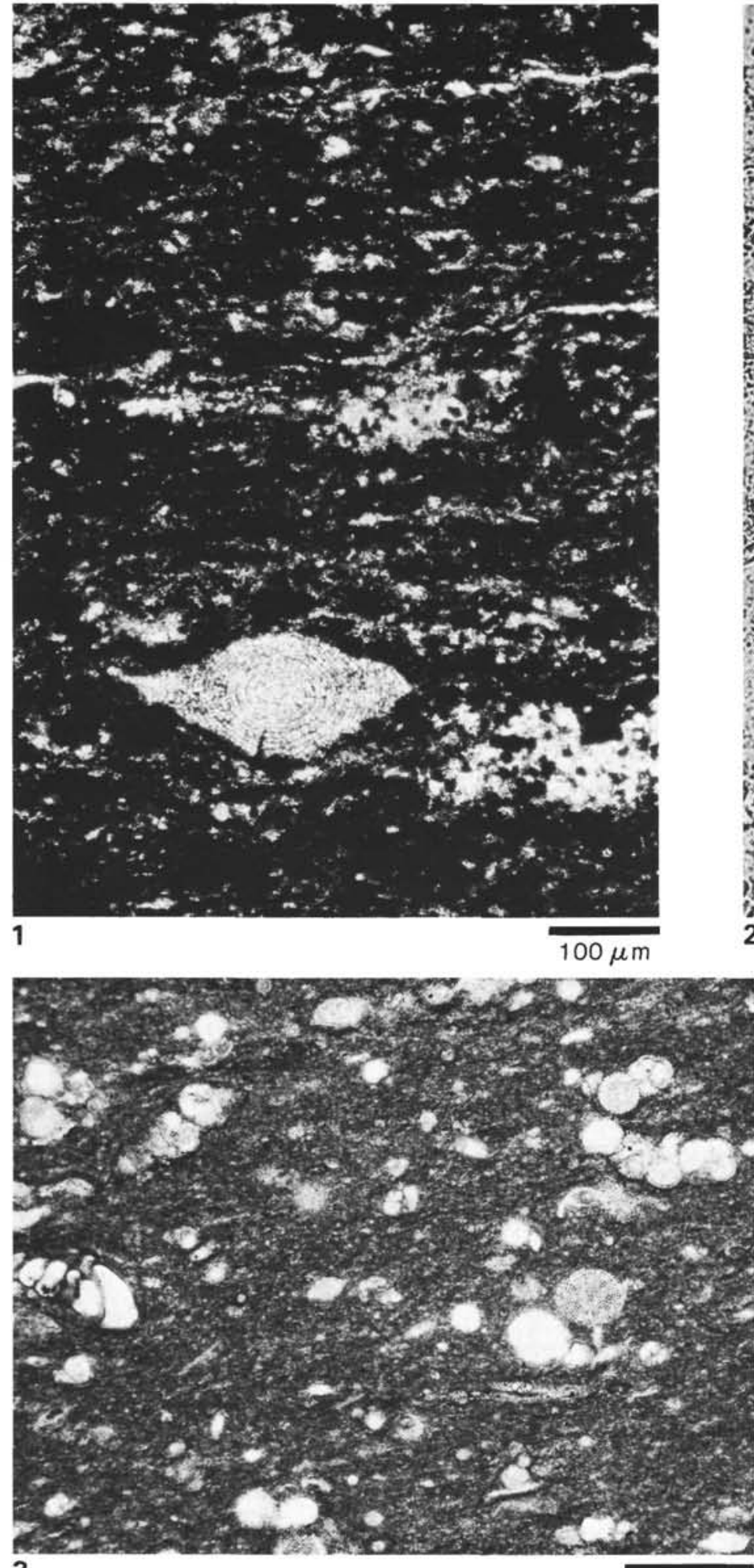

3

$50 \mu \mathrm{m}$

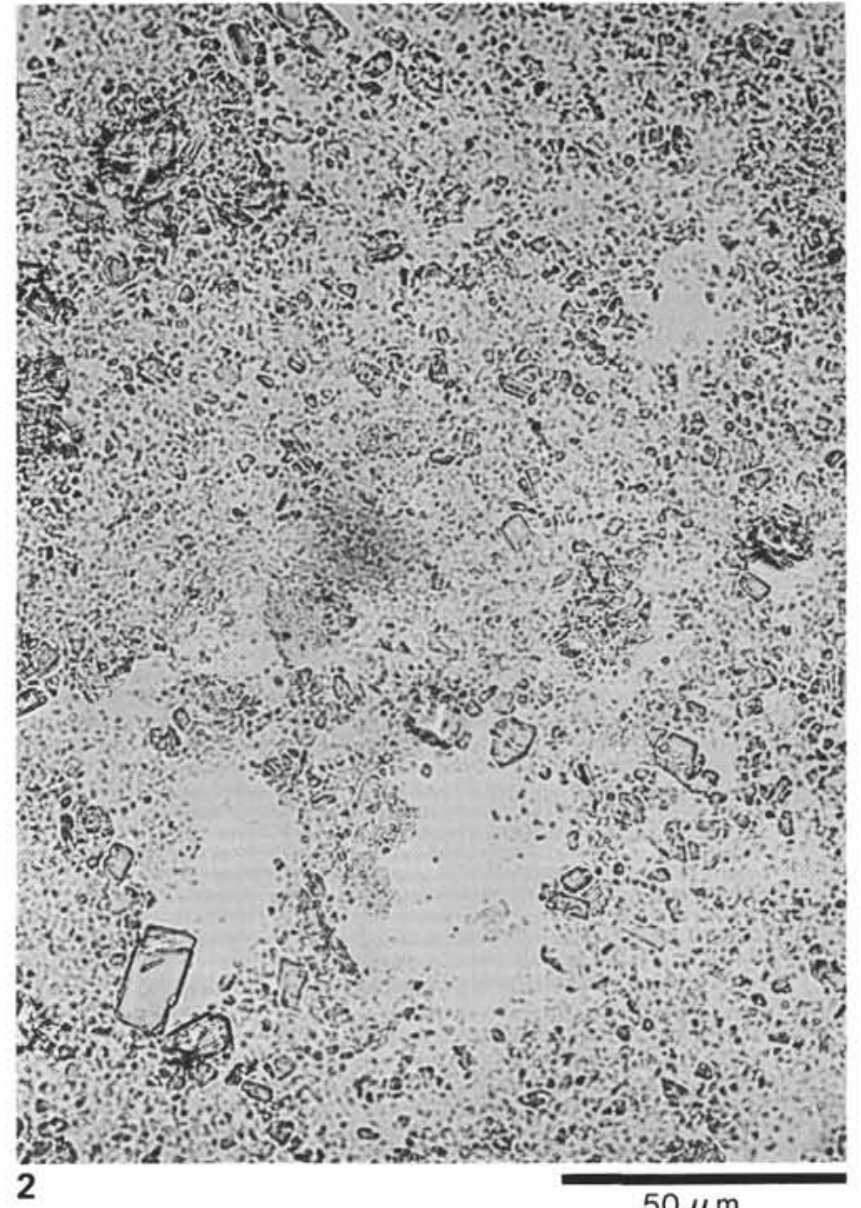

$50 \mu \mathrm{m}$

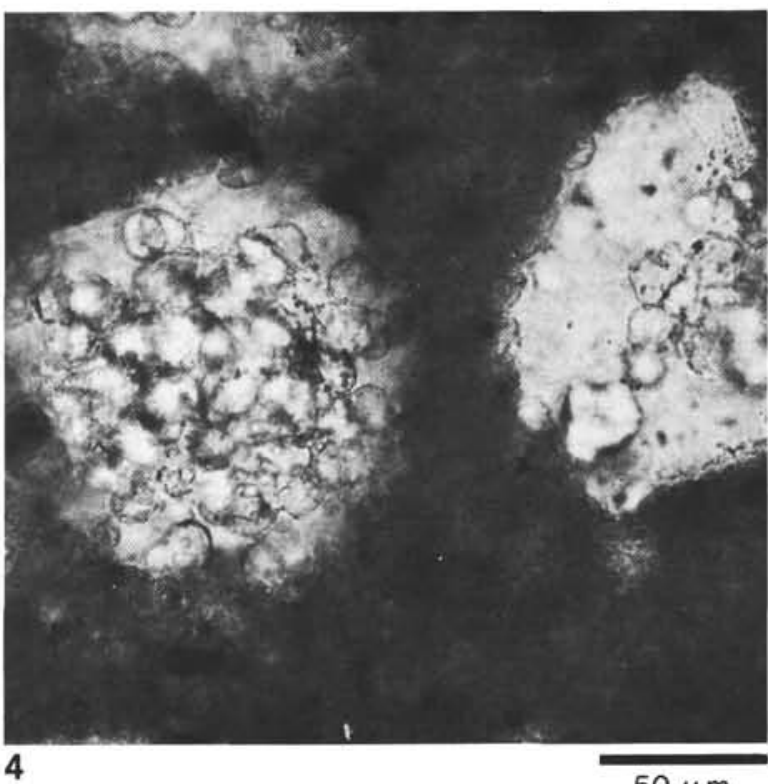

$50 \mu \mathrm{m}$

Plate 5. Silica diagenesis at Sites 603 and 605 (photomicrographs). 1. Porcellaneous quartz-silt and radiolarian-bearing organic matter and pyriterich shale with abundant opal-CT and clinoptilolite. Note well-preserved (although opal-CT-replaced) radiolarian. Sample 603B-34-1, 20-25 cm (Aptian-Albian). 2. Smear slide of same sample as thin section in Figure 1. 5: clinoptilolite and opal-CT-rich smectitic claystone. 3. Foraminiferal nannofossil marlstone with opal-CT replaced radiolarians and many "empty" radiolarian "ghosts." Sample 605-26-5, 76-80 cm (Unit III, upper lower Eocene). 4. Clay- and radiolarian-rich nannofossil limestone with fossil "ghosts" filled by calcite-replaced (former opal-CT) lepispheres. Sample 603B-82-2, 147-150 cm (Valanginian). 

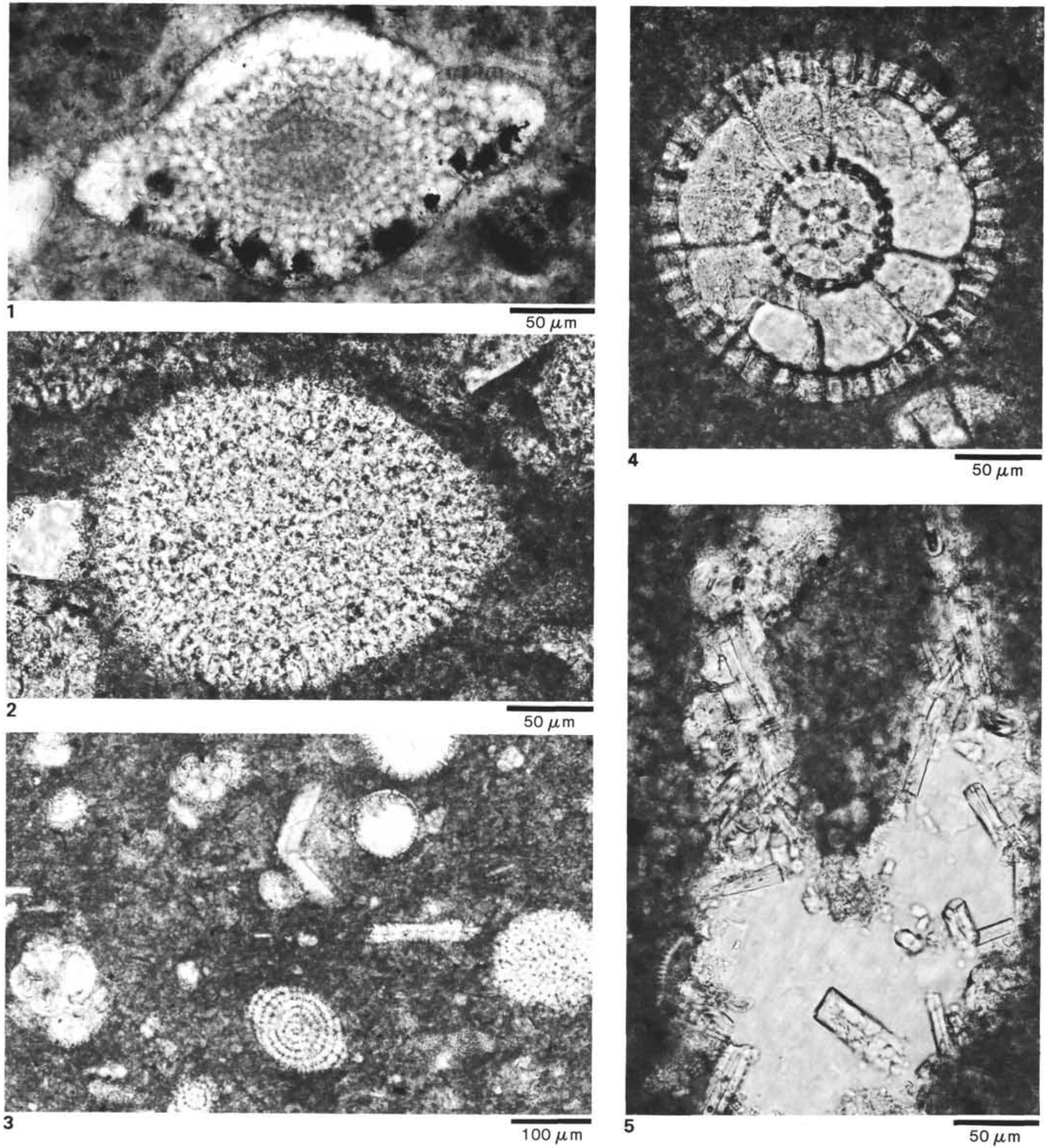

Plate 6. Diagenesis of radiolarians and other siliceous microfossils (photomicrographs). 1. Nannofossil marlstone with well-preserved (opal-A) radiolarian skeleton. Sample 604A-3-1, 4-6 cm (Miocene/Pliocene boundary). 2. Nannofossil marlstone with radiolarian "ghost," filled by opal-CT lepispheres. Sample 605-44-2, 95-99 cm (Unit III, upper lower Eocene). 3. Siliceous nannofossil chalk, with three well preserved opaline radiolarian skeletons, sponge spicules, and foraminifers. Sample 605-4-2, 95-99 cm (top of Unit II, middle Eocene). 4. Radiolarian skeleton (probably still unaltered opal-A) in radiolarian-bearing nannofossil chalk. Sample 605-23-5, 10-13 cm (Unit III, upper lower Eocene). 5 . Sponge-spicule-rich (spiculitic) siliceous nannofossil chalk. Sample 605-18-2, 141-146 cm (Unit II, middle Eocene). 

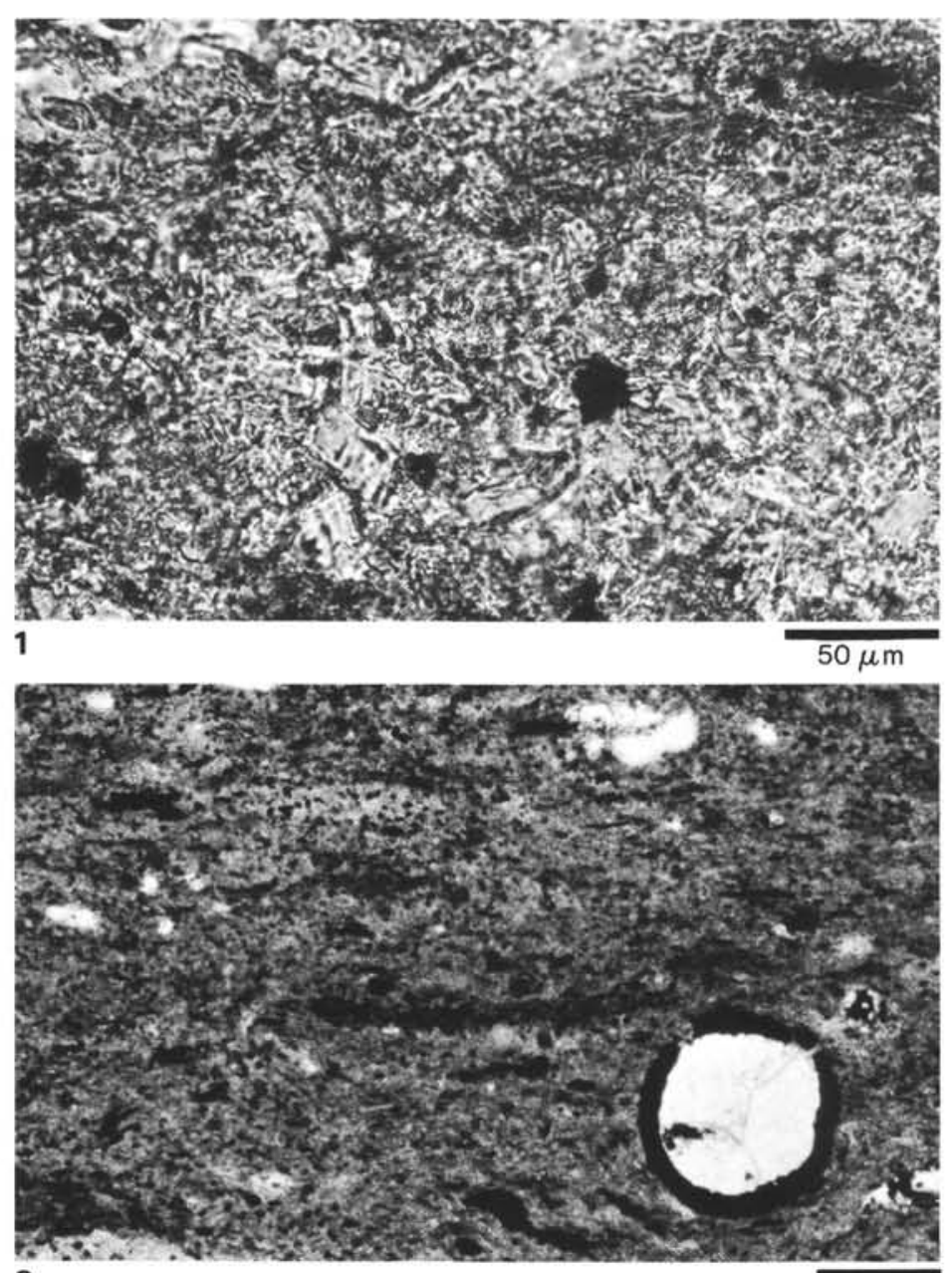

3

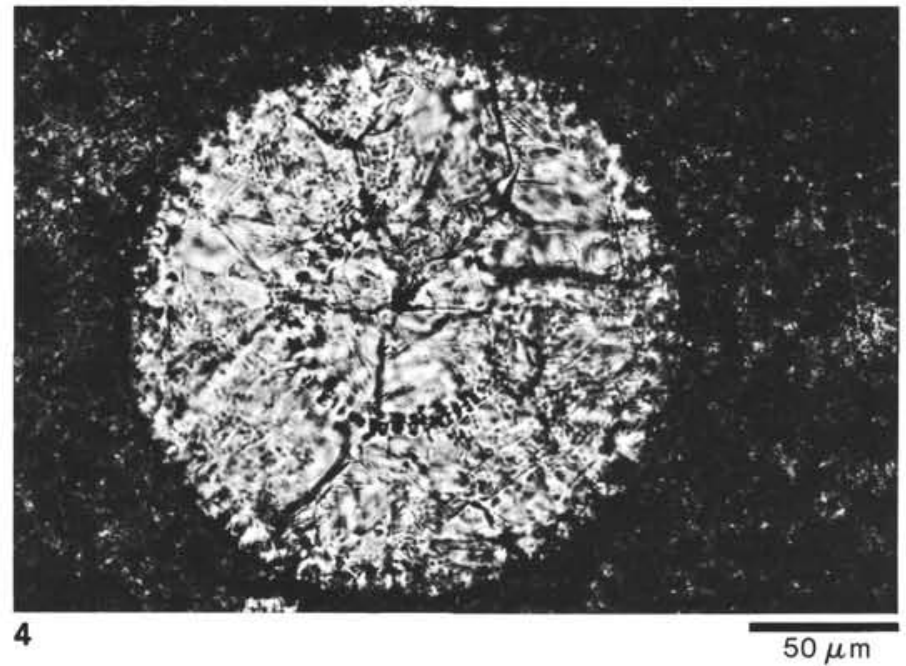

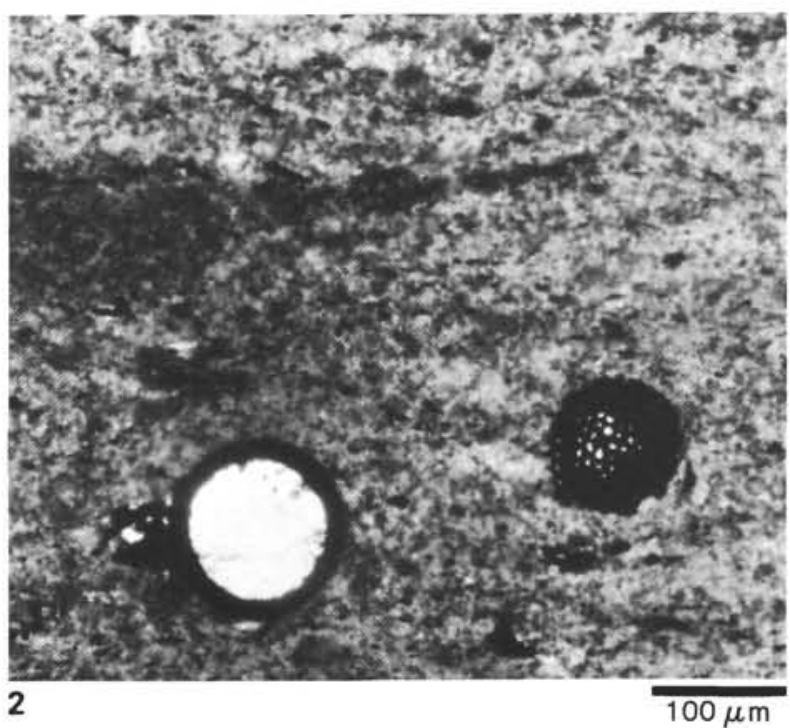

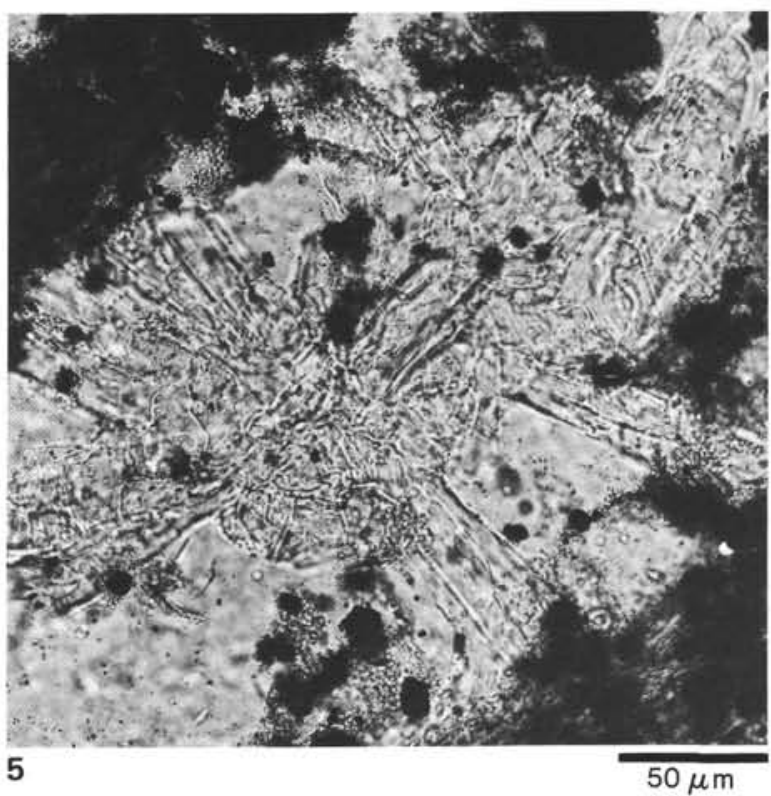

Plate 7. Zeolites and diagenesis of radiolarians (photomicrographs). 1. Organic matter and clay-rich zeolite siltstone with clinoptilolite laths. Sample 603B-34-5, 114-118 cm (Aptain-Albian). 2. Laminated nannofossil marlstone with pyritized radiolarians, filled by calcite. Sample 603B-55-1, 111-115 cm (Barremian). 3. Laminated nannofossil marlstone with radiolarian? "ghosts," pyritized and filled by calcite. Sample 603B-49-4, 9-13 cm (Barremian). 4. Nannofossil chalk with calcitized radiolarian. Note relict of inner skeleton. Sample 605-23-5, 10-13 cm (Unit III, upper lower Eocene). 5. Quartz-silt and mica-rich claystone with organic matter and clusters of twinned phillipsite? crystals. Sample 603B-68-1, 29.5-33 cm (Hauterivian). 


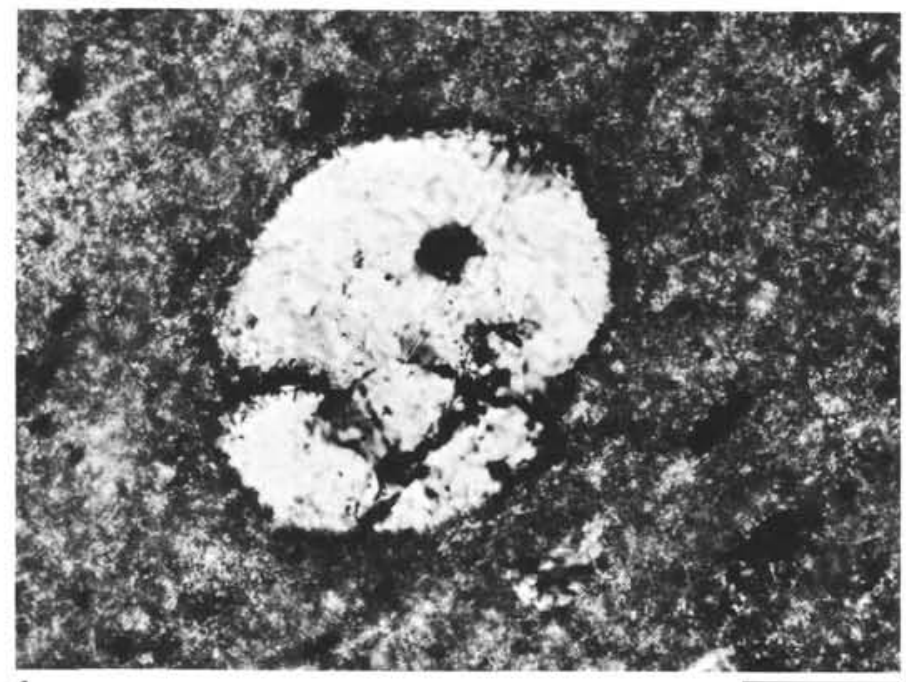

1

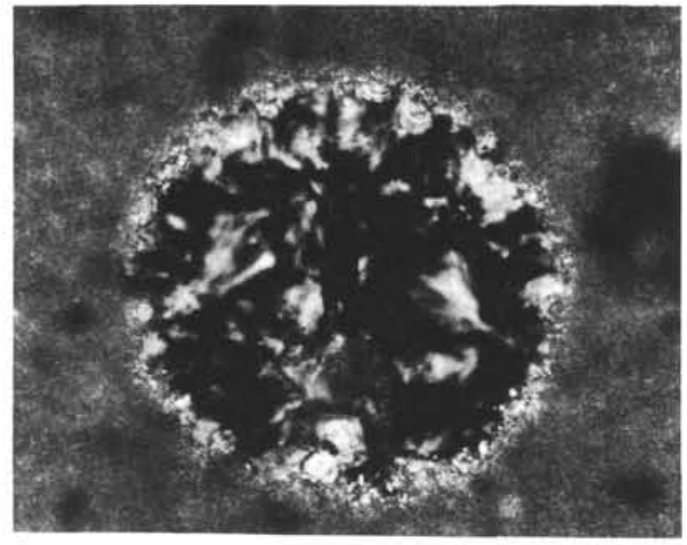

3

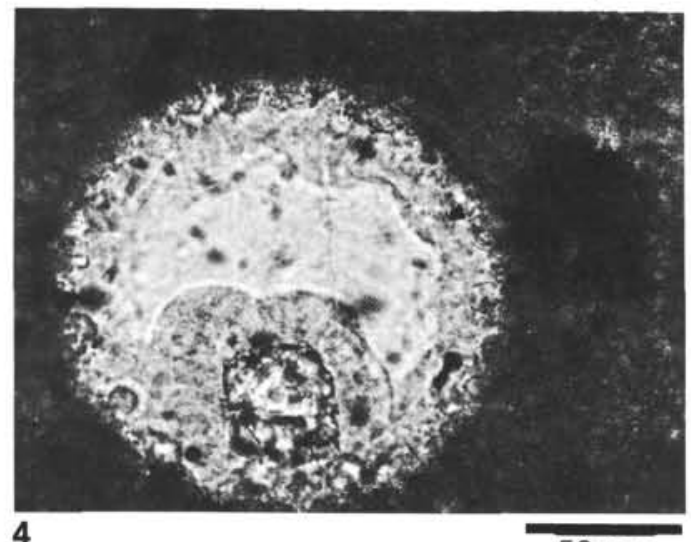

$50 \mu \mathrm{m}$

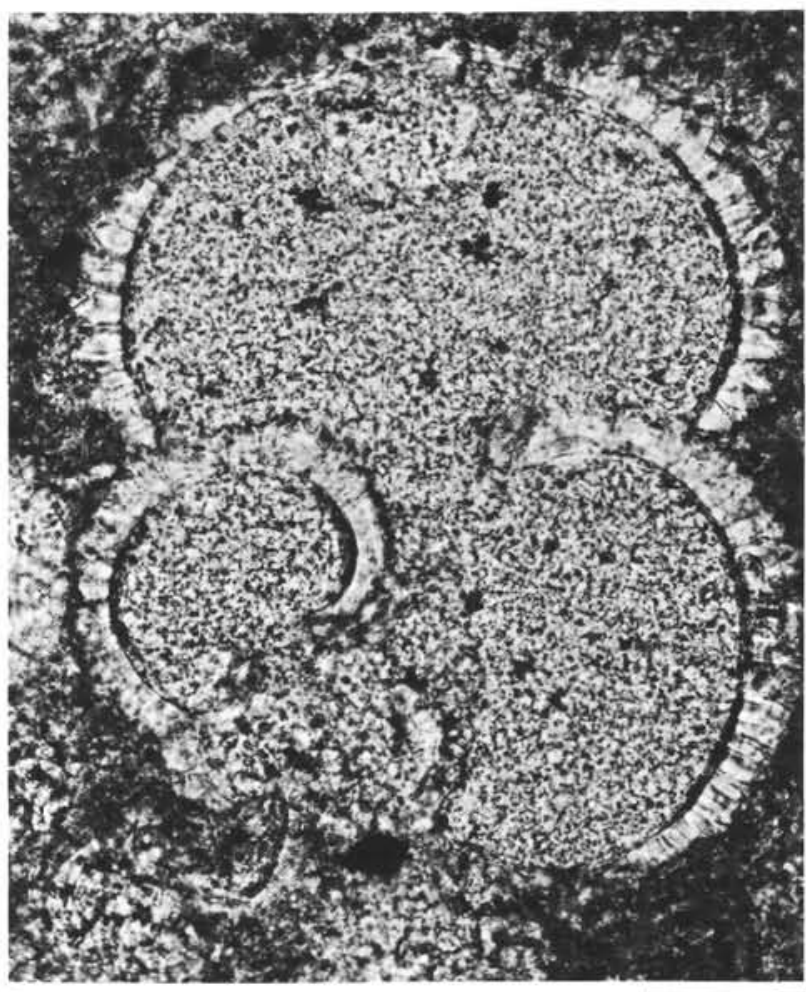

2

$50 \mu \mathrm{m}$

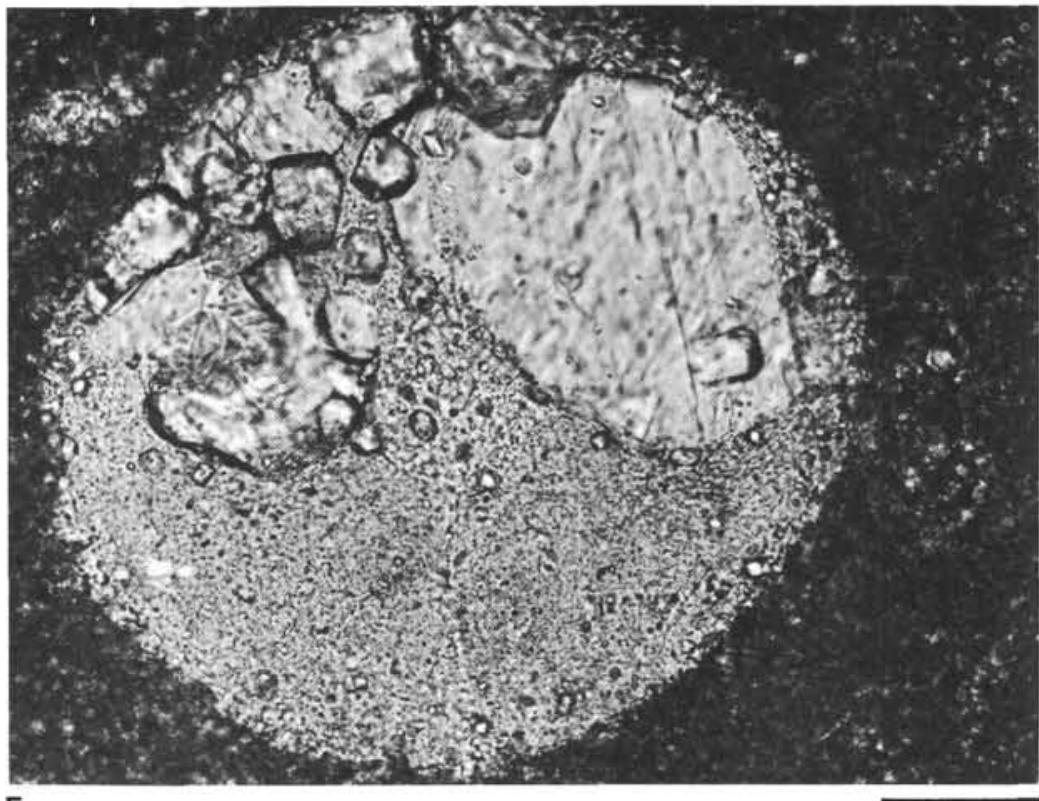

$50 \mu \mathrm{m}$

Plate 8. Diagenesis of radiolarians and foraminifers (photomicrographs). 1. Fossil "ghost" in upper Paleocene marlstone, filled by authigenic barite?-Sample 605-57-3, 98-100 cm. 2. Planktonic foraminifer, filled by smectite matrix. Sample 605-44-2, $95-99 \mathrm{~cm}$ (Unit III, upper lower Eocene). 3, 4. Nannofossil limestone with recrystallized radiolarian "ghost" (3) crossed nicols, (4) normal light. Note several generations of chalcedony (rim cement consisted originally of opal-CT lepispheres, subsequently filled by open-cavity growth of chalcedony). Sample 603B82-2, 147-150 cm (Valanginian). 5. Foraminiferal "ghost," filled by large calcite crystals and cryptocrystalline smectite. Sample 605-31-3, 21$24 \mathrm{~cm}$ (Unit III, upper lower Eocene). 


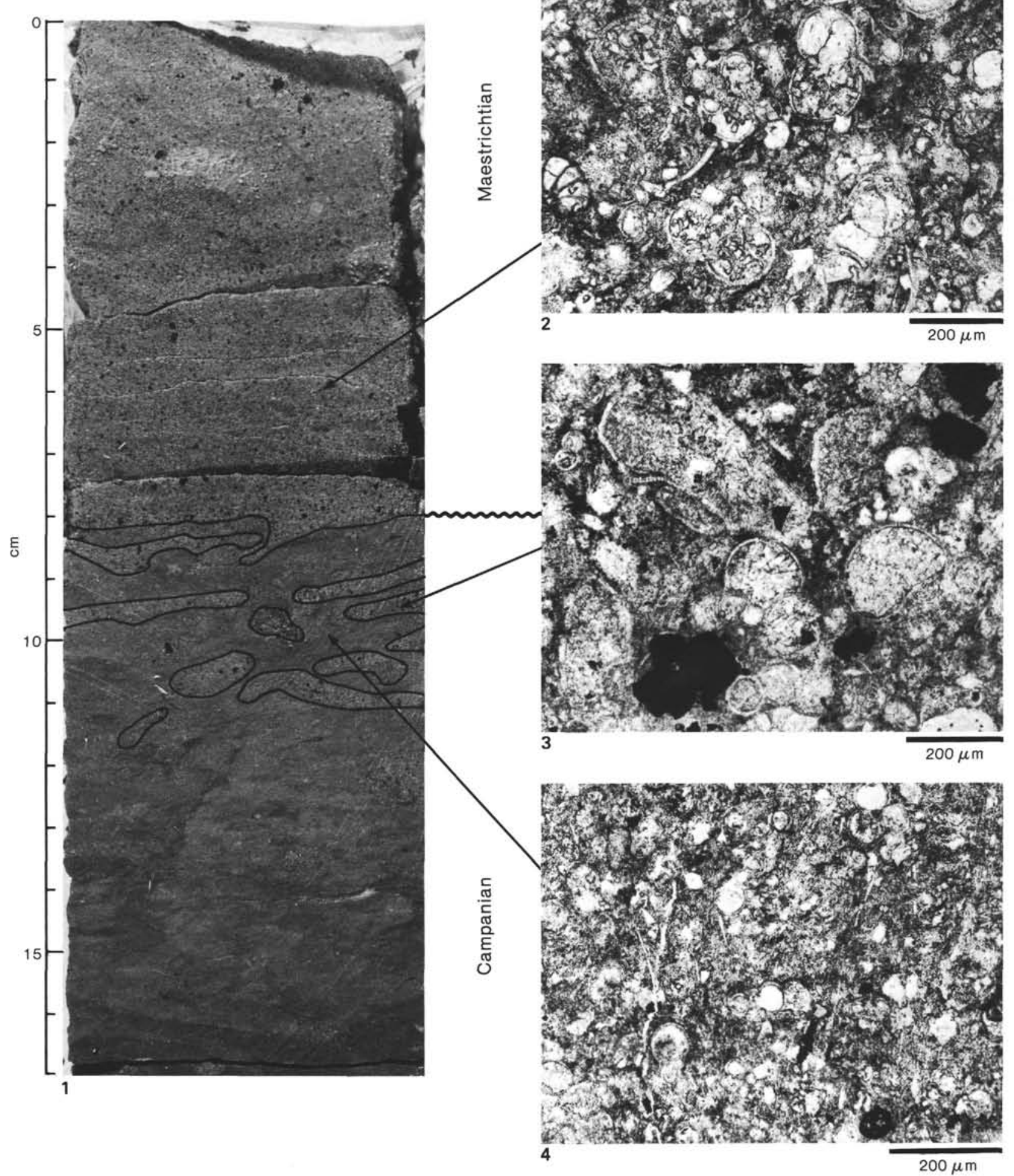

Plate 9. Diagenesis of foraminifers at Site 612 (core photo and photomicrographs). 1. Unconformity at Campanian/Maestrichtian boundary (Section 612-69-3). Glauconitic foraminiferal packstone of Maestrichtian age fills burrow structures at the top of Campanian black foraminiferal marls. 2. Maestrichtian foraminiferal packstone. Foraminifer chambers are filled with coarse sparitic calcite, clinoptilolite, and more rarely dolomite cement. 612-69-3, $6 \mathrm{~cm}$ (lower Maestrichtian). 3. Foraminiferal packstone in burrow structures. Foraminifer chambers are completely filled with microsparitic zeolites and smectite. Large crystals and crystal aggregates of pyrite are common. Sample 612-69-3, 9.5 cm (Campanian). 4. Clayey foraminiferal wacke- to packstone. Foraminifer chambers are mostly open or partially filled with calcitic, zeolitic, or smectitic rim cement. Sample 612-69-3, $10 \mathrm{~cm}$ (Campanian). 

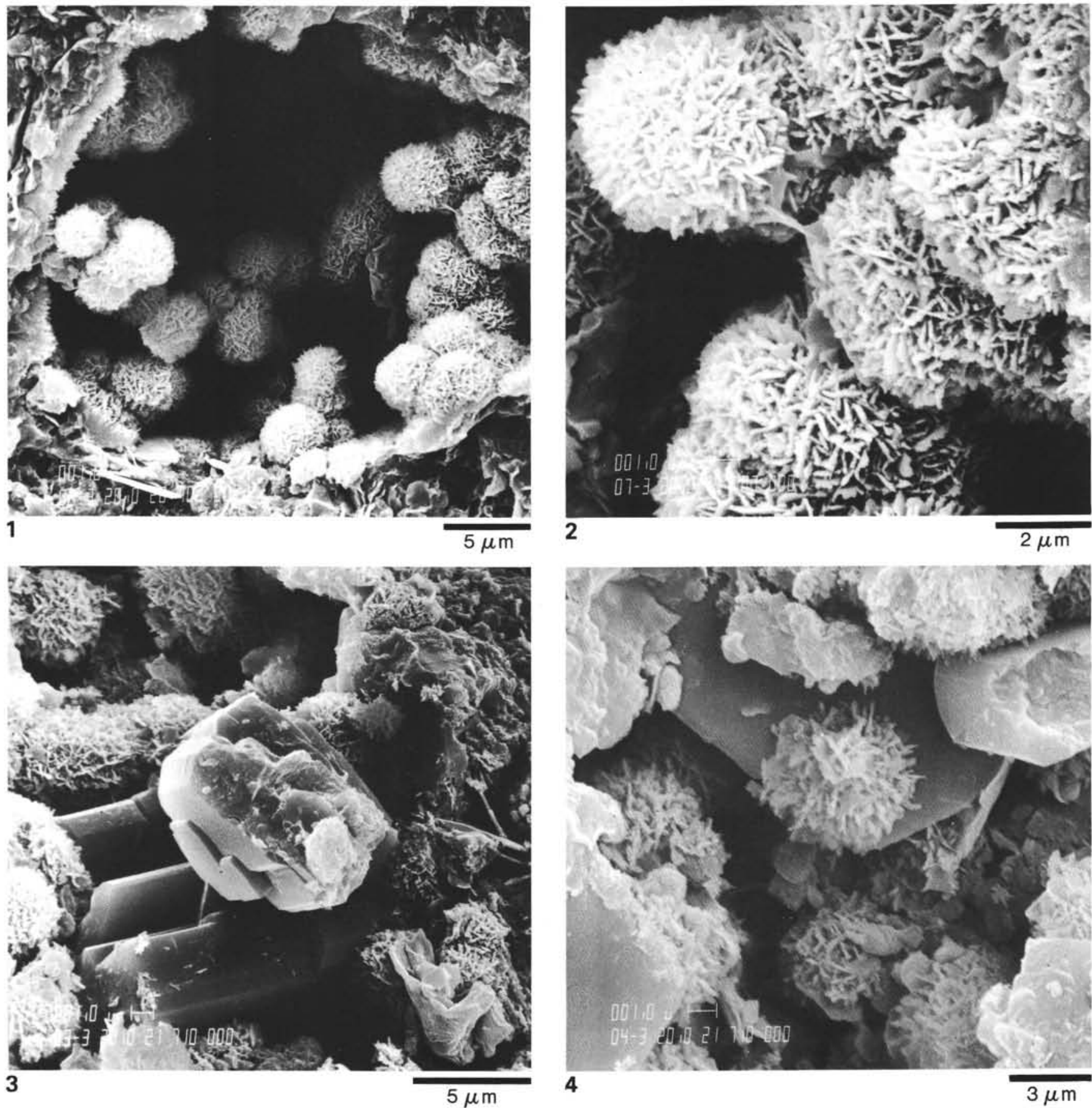

$2 \mu \mathrm{m}$

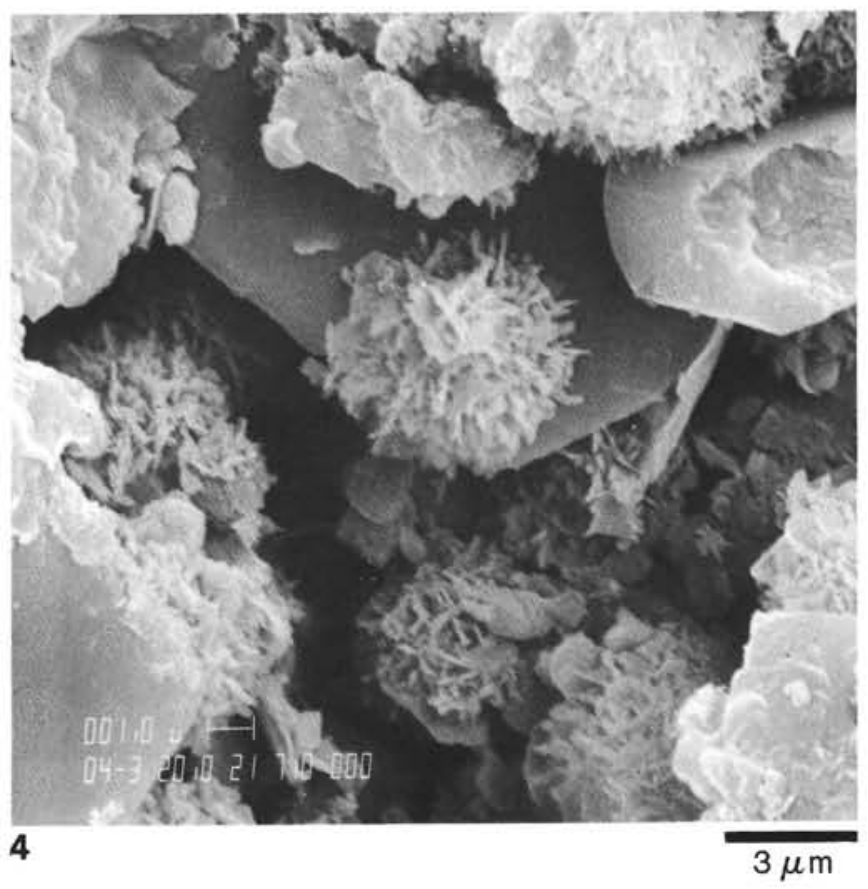

Plate 10. Scanning electron micrographs of opal-CT and clinoptilolite (Sites 603 and 605), 1, 2. Porcellanite with opal-CT lepispheres in radiolarian, "ghost"; (2) detail of same micrograph; note bladed lepispheres with regular $70^{\circ}$ or $180^{\circ}-70^{\circ}$ angle recording twinning law of tridymite (Flörke et al., 1976). Sample 603B-21-4, 121-122 cm (middle Eocene; SEM 1624/9+10). 3, 4. Stubby clinoptilolite crystals and opal-CT lepispheres in organic-rich black shale. (3) Note fine opal-CT blades incorporated into and penetrated by clinoptilolite crystals. (4) Lepisphere imprint on clinoptilolite crystal suggests that clinoptilolite is younger than opal-CT growth. Sample 603B-34-1, 20-25 cm (Aptian/Albian; SEM $1625 / 5+8)$. 

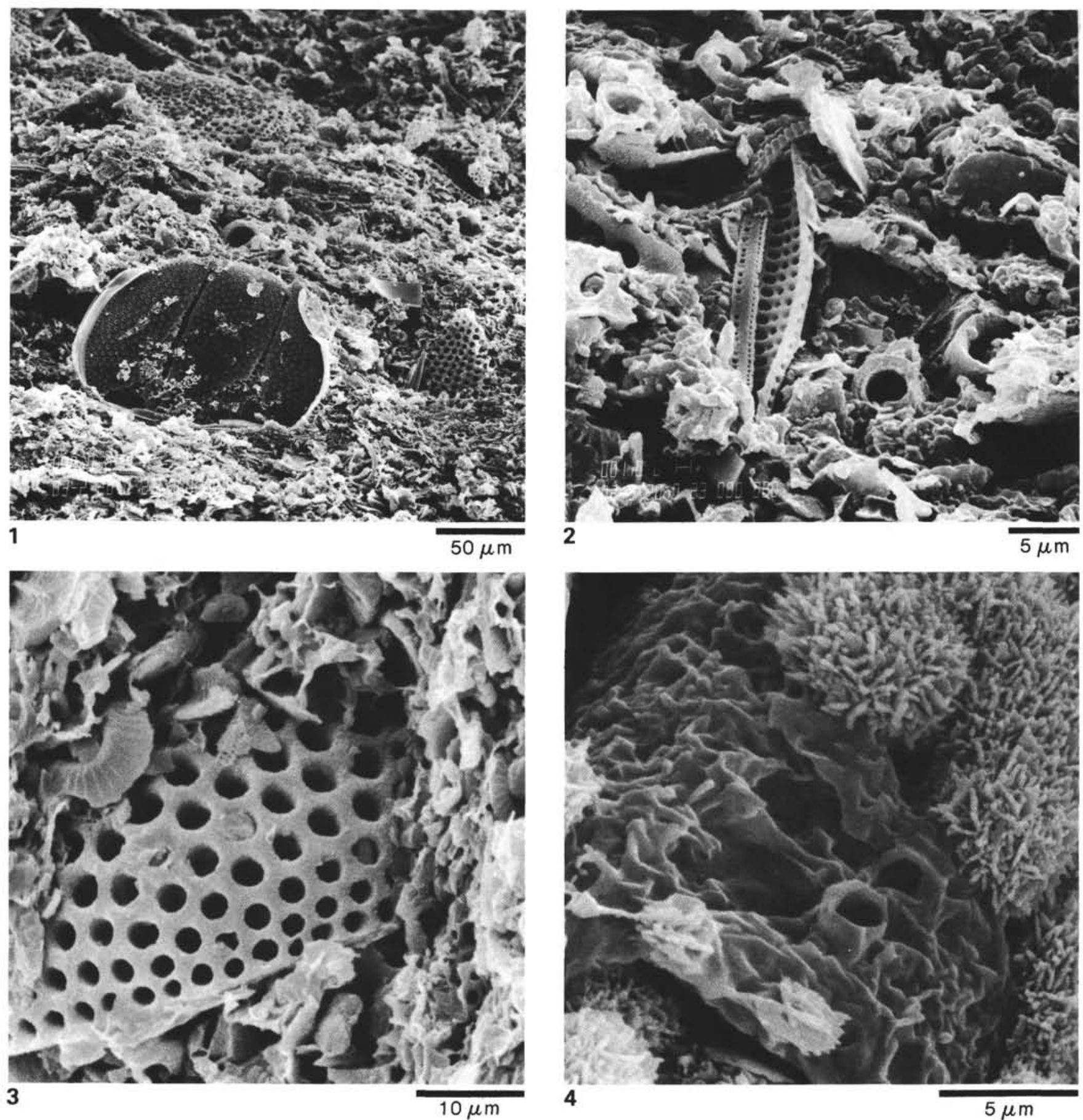

Plate 11. Scanning electron micrographs of opal-A and opal-CT. 1, 2. Biogenic silica-rich nannofossil chalk with coccoliths and well preserved opaline (opal-A) skeletons and fragments of diatoms and radiolarians. Sample 605-21-5, 98-100 cm (Unit II, mid-Eocene; SEM 1620/10+12). 3. Biogenic silica-rich nannofossil chalk with well preserved opaline diatom skeletons. Sample 605-18-2, 141-146 cm (Unit II, mid-Eocene; SEM 1639/8). 4. Weakly silicified nannofossil marlstone; note ghost of siliceous fossil (diatom?) overgrown by small incipient opal-CT lepispheres. Sample 605-37-1, 78-82 cm (Unit III, upper lower Eocene; SEM 1639/10). 


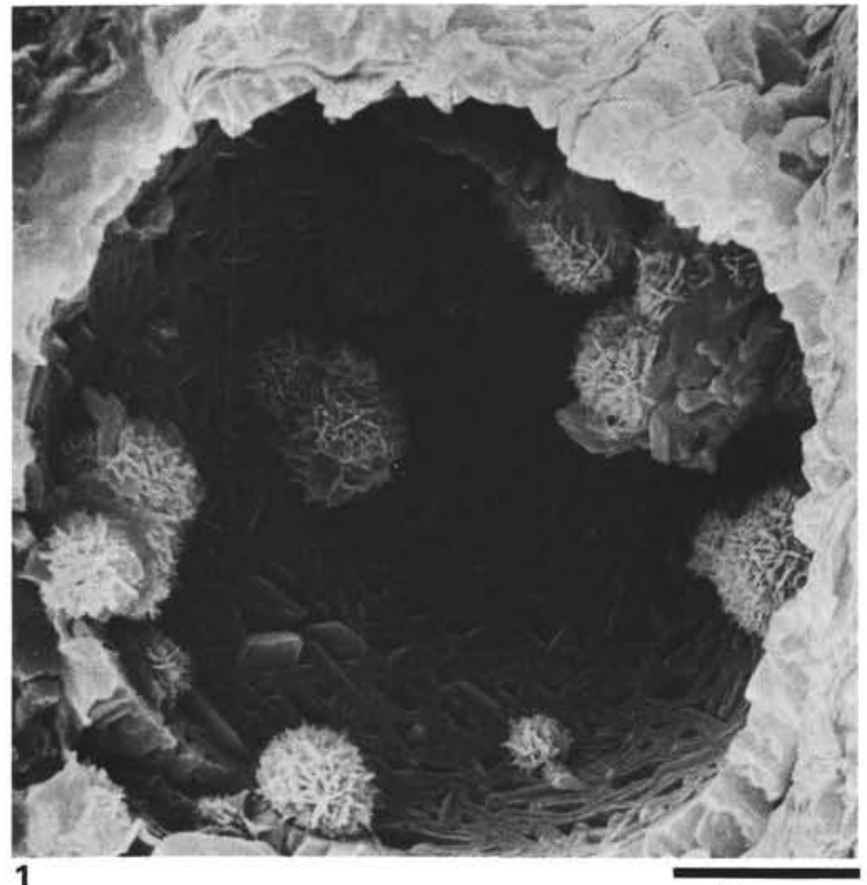

$10 \mu \mathrm{m}$

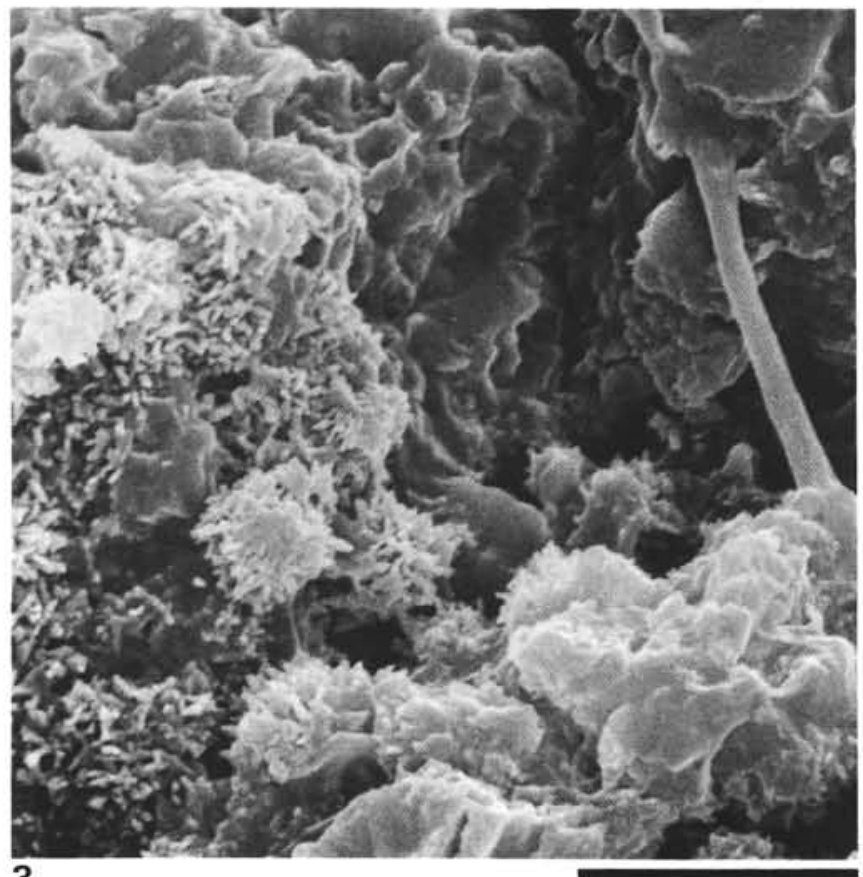

3

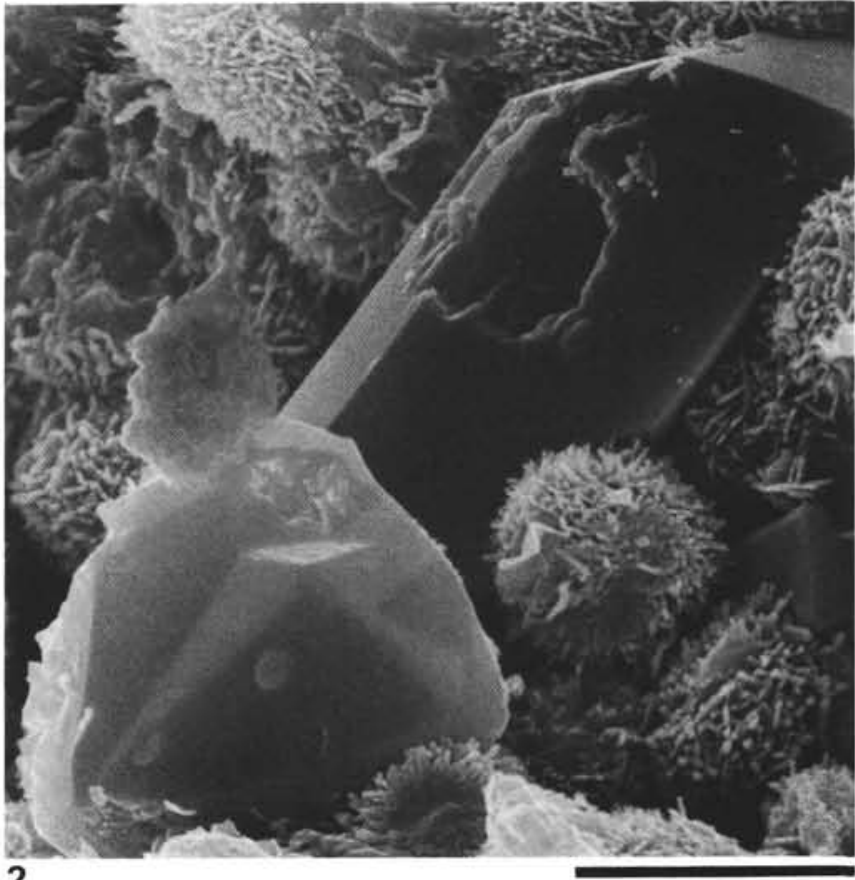

$10 \mu \mathrm{m}$

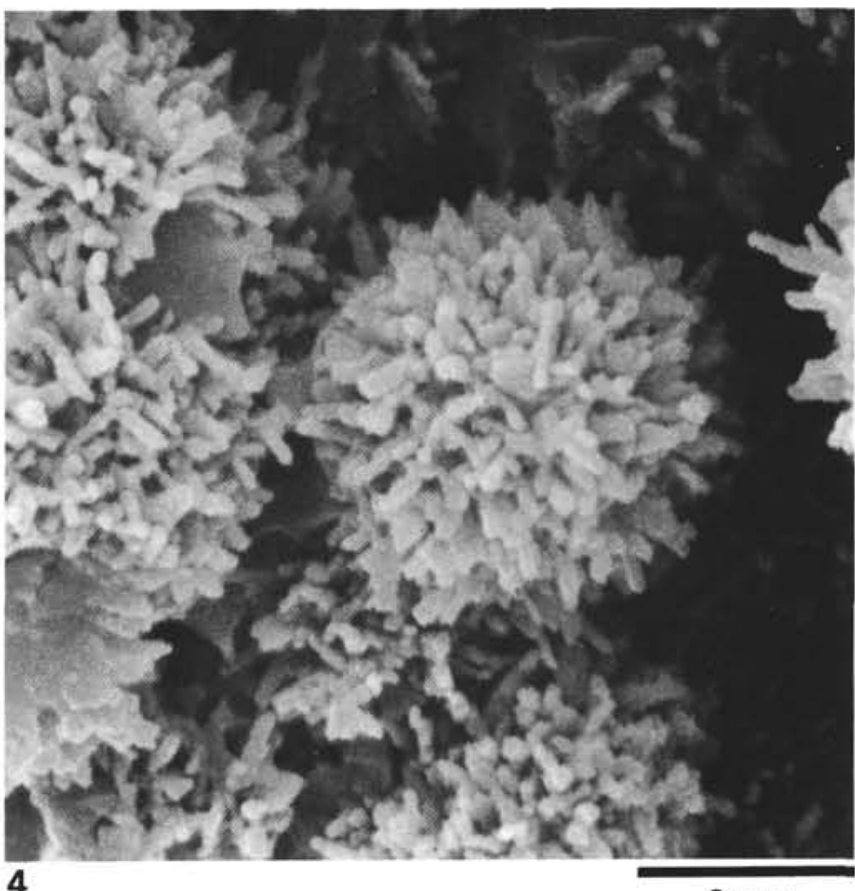

$3 \mu \mathrm{m}$

Plate 12. Scanning electron micrographs of porcellaneous nannofossil marlstones. 1, 2. Weakly silicified nannofossil marlstone; (1) note small lepispheres growing on foraminiferal? chamber and (2) authigenic clinoptilolite crystal. Sample 605-37-1, 78-82 cm (upper lower Eocene; SEM $1640 / 1+3$. 3, 4. Porcellaneous nannofossil marlstone with irregular, stubby opal-CT lepispheres (3) and normal lepispheres. Sample 605-55-2, 101-103 cm (Unit IV, upper Paleocene; SEM 1640/8+9). 